IZA DP No. 5259

Do Foreign-Owned Firms Provide Better Working Conditions Than Their Domestic Counterparts?

A Comparative Analysis

Alexander Hijzen

Pedro S. Martins

Thorsten Schank

Richard Upward

October 2010 


\title{
Do Foreign-Owned Firms Provide Better Working Conditions Than Their Domestic Counterparts? A Comparative Analysis
}

\author{
Alexander Hijzen \\ OECD and GEP, University of Nottingham \\ Pedro S. Martins \\ Queen Mary University of London, CEG-IST and IZA \\ Thorsten Schank \\ University of Mainz and IZA \\ Richard Upward \\ University of Nottingham and GEP
}

Discussion Paper No. 5259

October 2010

IZA

P.O. Box 7240

53072 Bonn

Germany

Phone: +49-228-3894-0

Fax: +49-228-3894-180

E-mail: iza@iza.org

Any opinions expressed here are those of the author(s) and not those of IZA. Research published in this series may include views on policy, but the institute itself takes no institutional policy positions.

The Institute for the Study of Labor (IZA) in Bonn is a local and virtual international research center and a place of communication between science, politics and business. IZA is an independent nonprofit organization supported by Deutsche Post Foundation. The center is associated with the University of Bonn and offers a stimulating research environment through its international network, workshops and conferences, data service, project support, research visits and doctoral program. IZA engages in (i) original and internationally competitive research in all fields of labor economics, (ii) development of policy concepts, and (iii) dissemination of research results and concepts to the interested public.

IZA Discussion Papers often represent preliminary work and are circulated to encourage discussion. Citation of such a paper should account for its provisional character. A revised version may be available directly from the author. 


\section{ABSTRACT \\ Do Foreign-Owned Firms Provide Better Working Conditions Than Their Domestic Counterparts? A Comparative Analysis}

This paper analyses to what extent working conditions in foreign-owned firms differ from those in their domestic counterparts. It makes three main contributions. First, we replicate the consensus in the empirical literature by applying a standardised methodology to firm-level data for three developed (Germany, Portugal, UK) and two emerging economies (Brazil, Indonesia). We show that, consistent with previous evidence, foreign-owned firms offer substantially higher average wages than domestic firms and that this difference is particularly important in emerging economies. Second, we show that these positive wage effects of foreign takeovers reduce in size when controlling for changes in the composition of the workforce, although they tend to remain positive and statistically significant. However, the wage effects associated with worker movements from domestic to foreign firms are potentially important, particularly in emerging economies. Third, we look not only at wage outcomes but also consider other working conditions such as working hours, job stability and union coverage. We find that foreign takeovers of domestic firms tend to have a small positive effect on wages, but little effect on other aspects of working conditions.

JEL Classification: F14, F16, F23

Keywords: foreign direct investment, foreign wage premia

Corresponding author:

Pedro Martins

School of Business and Management

Queen Mary, University of London

Mile End Road

London E1 4NS

United Kingdom

E-mail: p.martins@qmul.ac.uk

\footnotetext{
* The authors would like to thank Andrew Clark, Luiz Esteves, Stefano Scarpetta and Paul Swaim, participants of the 2008 CAED conference (Budapest), a research workshop of the Research Institute of Industrial Economics (Stockholm), and the World Bank/IZA conference on Employment and Development (Rabat) and seminar participants in Paris and Tokyo for helpful comments and suggestions. The opinions expressed in this paper are those of the authors and do not necessarily reflect those of the OECD or its member states. All remaining errors are our own.
} 


\section{Introduction}

Is it better to work for a multinational or a national firm? Until recently, a large empirical literature had reached a consensus that foreign firms pay higher wages than their domestic counterparts. ${ }^{1}$ However, with the increasing availability of linked employer-employer data (LEED) this consensus has been challenged. For example, Martins (2004) for Portugal and Heyman et al. (2007) for Sweden show that, after controlling for both worker and firm characteristics, the effects of foreign ownership may disappear or even become negative. This seems to be because, essentially, foreign-owned firms select on worker quality: workers in foreign-owned firms would have earned more even had they worked for domestically-owned firms. However, other studies, including Andrews et al. (2009) for Germany, Malchow-Moller et al. (2007) for Denmark and Balsvik (2007) for Finland, point at positive, albeit small, wage effects.

It is not clear what drives the differences in estimated wage premia across studies. They may reflect differences in country characteristics or the nature of FDI. However, it is also possible that they reflect differences in the econometric methodology. Moreover, the use of linked employer-employee data has been limited to developed countries, and it is an open question what the effect of controlling for firm and worker selection would be for the estimation of foreign wage premia in developing countries, where such premia are believed to be much larger (Moran, 2006).

Less attention has been directed towards the effects of foreign ownership on other aspects of workers' employment conditions, and the extent to which multinational enterprises (MNEs) export working conditions abroad. An important exception is a recent study by Bloom et al. (2009) who use survey data on management and work-life balance practices to analyze to what extent US multinationals export such practices to their affiliates in Europe. There is also far less evidence on the impact of foreign ownership on different groups of workers. While a number of studies have analysed how foreign ownership affects the wages of skilled and unskilled workers, very few studies attempt to go beyond this. Heyman et al. (2006) provide a notable exception in their study of the effects of cross-border takeovers on wage dispersion.

The contribution of the present paper is threefold. First, we replicate the consensus in the empirical literature by applying a standardised methodology to firm-level data for three developed and two emerging economies. Second, we provide internationally comparable evidence on the role of foreign ownership for

\footnotetext{
${ }^{1}$ Note that most researchers have focused on pay differences between foreign-owned and domestic firms because the available data often do not identify multinational firms, and this is also the approach we take here.
} 
average wages that controls for worker selection using worker-level data for four countries. ${ }^{2}$ Third, in contrast to much of the empirical literature, the present paper is not limited to analysing the average effects of foreign ownership on wages, but expands the focus to a wider set of wage and non-wage working conditions. It analyses the wage effects of foreign ownership across three different skill groups and lowpaid workers. It also considers how foreign ownership affects hours of work, job stability and union coverage.

The role of foreign ownership for wages and working conditions is identified by focusing on changes in ownership status as a result of cross-border acquisitions or worker movements. In order to overcome the problem of selection bias that is associated with the non-random nature of firm acquisitions and worker movements the study makes use of propensity score matching in combination with difference-indifferences methods. ${ }^{3}$

Our main findings are as follows. First, we replicate the consensus in the empirical literature that was based on firm-level studies of cross-border takeovers, by showing that foreign-owned firms offer substantially higher average wages than domestic firms and that this difference is particularly important in emerging economies. Second, we show, using linked employer-employee data for four countries, that these positive wage effects of foreign takeovers reduce substantially when controlling for changes in the composition of the workforce, although they tend to remain positive and statistically significant. However, the wage effects associated with worker movements from domestic to foreign firms are potentially important, particularly in emerging economies. Third, going beyond average wages, we find little systematic evidence for the role of foreign ownership for other aspects of working conditions.

The remainder of this paper is structured as follows. Section 2 discusses under what circumstances foreignowned firms may have incentives to offer different wages and better working conditions to similar workers doing similar jobs to their local counterparts. Section 3 discusses the empirical literature on the effects of foreign ownership on wages and working conditions. Section 4 discusses the various data sources used and their comparability across countries. Section 5 presents the econometric methodology and Section 6 presents the results. The final section presents some concluding remarks.

\footnotetext{
${ }^{2}$ Indonesia is excluded from this part of the analysis for reasons of data availability.

${ }^{3}$ This method will yield estimates of causal effects if the unobservable determinants of firm acquisitions or worker mobility are fixed over time.
} 
In a perfectly competitive setting, firms are price-takers in output and input markets and all workers are paid their marginal product. Consequently, one would expect foreign-owned firms to offer similar pay and working conditions to individuals with similar characteristics doing similar jobs. However, one might still find differences in wages between domestic and foreign-owned firms, for two reasons.

First, in competitive labour markets, wages and working conditions are substitutes: pay differences are used to compensate for differences in working conditions that are valued by workers. For example, it is sometimes suggested that jobs are less secure in foreign-owned firms because they are "footloose" or have more elastic labour demand. This could provide a rationale for foreign-owned firms to offer higher wages than their local competitors to compensate for lower job security. Conversely, workers may be willing to accept working for lower pay in foreign-owned firms initially if there is the possibility of subsequent training and career development. In short, wages might differ between foreign-owned and domestic firms because the quality of jobs differs.

Second, there may be average pay differentials at the firm-level due to differences in workforce composition and human-resource practices between multinational and domestic firms. For example, foreign-owned and domestic firms may hire different types of workers. Alternatively, it may be that foreign-owned and domestic firms have different human-resource practices related to, for example, the importance of training, on-the-job learning and career development. As a result, workers with similar characteristics at the start of a job develop differently, thereby giving rise to pay differentials.

In non-competitive labour markets, differences in pay and working conditions between foreign-owned and domestic firms may occur even for individuals with similar characteristics doing a similar job, for several reasons. First, search frictions reduce the degree to which arbitrage takes place across firms due to differences in labour productivity for identical workers. As a result, high-performance firms may derive monopsony power from their ownership advantage, allowing them to pay their workers less than their marginal value product, but more than their local competitors. In most search models it is assumed that wages are determined through Nash bargaining. This implies that high-performance firms are likely to pay higher wages and provide better working conditions. ${ }^{4}$ If foreign firms tend to be high-performance firms,

\footnotetext{
${ }^{4}$ The cost-saving that can be achieved by a MNE thanks to its monopsony power is likely to fall with the availability of comparable jobs outside the MNE which may be closely related to the level of economic development. Decreuse and Maarek (2007) refer in this context to a technology-rent effect, which allows MNEs to derive monopsony power from their technological advance, and a competition-wage effect, that follows from the competition between firms for
} 
as is typically assumed (Helpman et al., 2004), workers in such firms may be expected to receive better working conditions than their counterparts in less productive domestic firms.

Second, rather than having an ad hoc rule to distribute rents between firms and workers, market failures may interact with firm characteristics to give rise to differences in the way rents are distributed across firms, even after controlling for differences in productivity. ${ }^{5}$ Firms that derive their productivity advantage from firm-specific knowledge may wish to provide better working conditions in the hope that this would reduce worker turnover and minimize the risk of their productivity advantage spilling over to competing firms (Fosfuri et al., 2001; Glass and Saggi, 2002). Foreign-owned firms may also differ in terms of monitoring costs, managerial responsiveness to industrial-relations demands and in their preferences over the use of pay incentives to motivate the workforce. Finally, firms may differ in terms of their bargaining power relative to trade unions, because they differ in terms of their outside options. In sum, efficiencywage arguments based on the role of firm-specific assets and pay incentives may explain why foreignowned firms provide better working conditions to individual workers than their local counterparts, while foreign-owned firms may be less inclined to give in to trade union demands as they may be able to relocate production activities to another country.

The extent to which foreign-owned firms offer better pay and working conditions than their local counterparts for similar workers doing a similar job may vary across the country of ownership and the countries in which they operate, as well as between different groups of the workforce. We hypothesise that the gap in working conditions between foreign-owned and domestic firms will be greater in developing countries because the technological difference is likely to be greatest, and the availability of comparable alternative job opportunities lowest. ${ }^{6}$ We also hypothesise that foreign-owned firms will offer relatively better working conditions for skilled workers. Worker turnover of skilled workers is more likely to lead to the dispersion of firm-specific knowledge, thereby undermining the productivity advantage of foreign-

labour services. See also Martins and Yong (2010), who study rent sharing between multinational parents and their affiliates and find stronger links when affiliates are more distant from their parents.

${ }^{5}$ In fact, the arguments discussed here provide a rationale for assuming Nash-bargaining in search models of the labour market.

${ }^{6}$ Egger and Kreickemeier (2009) develop a model which shows that this does not necessarily have to be the case as this depends on the relative average productivities of multinational and national firms in developed and developing countries. However, given the large average differences in productivity between national firms in developed and developing countries this seems a reasonable conjecture. 
owned firms. ${ }^{7}$ To the extent that it takes time to acquire firm-specific knowledge, the incentive to offer better working conditions should also increase with job tenure, particularly among skilled workers.

\section{$3 \quad$ Empirical literature}

\subsection{Firm-level evidence}

There is a large empirical literature on foreign wage premia. Because data limitations generally do not allow distinguishing between multinational and national firms, most studies have focused on pay differences between foreign-owned and domestic firms instead. Until recently, there was a consensus that foreign firms tend to pay higher wages than their domestic counterparts, particularly in developing countries. In an early study for Mexico, the US and Venezuela, Aitken et al. (1996) show that average wages in foreign-owned plants are about 30\% higher than in domestic plants. These wage differences persist after controlling for size, geographic location, skill mix and capital intensity in Mexico and Venezuela, but not in the United States. This suggests that foreign-owned firms pay higher wages than their local competitors in developing countries. However, this does not necessarily mean that foreign ownership improves employment conditions when a domestic firm is being taken over by a foreign firm. Foreign firms may cherry-pick the best domestic firms on the basis of characteristics that are not controlled for in the regression analysis, but are associated with higher average wages. One such variable is the quality of the labour force. In order to address this possibility, subsequent studies have analyzed the extent to which foreign wage premia persist after controlling for observable measures of worker quality as well as unobservable time-invariant firm fixed effects. ${ }^{8}$

Most recent studies focus on cross-border takeovers to analyze the causal effect of a change in ownership status on worker outcomes by making use of firm-level panel data. The main advantage of panel data is that it allows one to control for firm-selection, i.e. the possibility that foreign-owned plants differ from

\footnotetext{
${ }^{7}$ However, in developing countries where the respect for basic labour and human rights may present real problems, reputation-sensitive foreign firms may also have strong incentives to offer better conditions to low-skilled workers. See Harrison and Scorse (2010) for an analysis of the impact of anti-sweatshop activism in the US on wages and employment in the foreign suppliers of US multinationals in Indonesia.

${ }^{8}$ For example, Lipsey and Sjöholm (2004) ask whether foreign wage premia may simply reflect differences in worker composition between foreign and domestic firms. In order to address this possibility, they use a plant-level dataset for Indonesia with detailed information on the composition of workers across educational categories. They find that, while differences in average labour quality account for a significant part of the raw foreign wage premium, foreign wage premia remain large, i.e. wages in foreign-owned plants are $12 \%$ higher for production workers and $20 \%$ for non-production workers. Te Velde and Morrissey (2003) present similar findings for five Sub-Saharan African countries.
} 
domestic plants because foreign investors select their targets on the basis of unobservable time-invariant characteristics rather than ownership status per se. Girma and Görg (2007) find, for the UK, that foreign takeovers of domestic firms tend to increase wages, but also that their effect depends on the industry of target firms and the nationality of acquirers. For Indonesia, Lipsey and Sjöholm (2006) find that even after controlling for firm-fixed effects, foreign takeovers raise production workers' wages by $17 \%$ and nonproduction workers' wages by 33\%. More generally, these studies show that controlling for fixed effects reduces the estimated foreign wage premium without, however, challenging the basic finding that foreignowned firms pay higher wages than domestic firms.

\subsection{Evidence from linked employer-employee data}

The results from firm-level studies may be somewhat misleading because they do not control for worker selection, i.e. the possibility that ownership changes are associated with changes in the composition of the workforce. To the extent that unskilled workers tend to leave after takeovers and skilled workers join, this would bias the estimated foreign wage premium upwards. Using linked employer-employee data, it is possible to control for changes in the composition of the workforce by focusing on the wage effects for individual workers who stay in the same firm. Those data also allow one to look at the role of ownership for workers who change jobs between domestic and foreign firms. This is interesting because it allows an analysis of differences in pay conditions between foreign and domestic firms for new workers. As productivity differences may have more important implications for workers at the moment of hiring than for stayers (Beaudry and DiNardo, 1991; Pissarides, 2009), one may expect the role of ownership to be more important for this category of workers. ${ }^{9}$

An increasing number of studies have made use of linked employer-employee data to analyse the role of foreign ownership for individual wages. The results challenge the conventional wisdom by suggesting that foreign takeovers in developed countries have, at best, a small positive effect on individual wages and that this effect could even be negative. For example, Martins (2004) shows for Portugal that the foreign wage premium disappears after controlling for worker selection and may even reduce individual wages by $3 \%$ for workers in foreign firms relative to their counterparts in domestic firms. Heyman et al. (2007a) present similar findings for Sweden which also indicate that foreign takeovers may reduce individual wages relative to their counterparts in domestic firms, while Andrews et al. (2009) for Germany, Malchow-Moller et al. (2007) for Denmark and Balsvik (2007) for Finland find small positive effects (1\%-3\%). Relatively

\footnotetext{
${ }^{9}$ In addition, the analysis of worker movements takes account of both foreign-owned firms that were previously domestic, but have been acquired by a foreign owner, and those that are established through "Greenfield” investment.
} 
few studies exploit worker mobility to analyse the role of foreign ownership. Two exceptions are Andrews et al. (2009) and Balsvik (2006), who show that workers moving from a domestic to a foreign firm experience a $6 \%$ increase in wages in Germany and $8 \%$ in Norway. ${ }^{10}$ These findings may indicate that the short-term effects of foreign ownership may be more important for new hires in foreign firms than workers who stay in firms that change ownership. Table 1 summarises the previous empirical literature on foreign wage premia.

\section{[Insert Table 1]}

Overall, the recent evidence based on worker-level data provides a somewhat mixed message with respect to the impact of foreign ownership on wages. While most studies indicate that foreign ownership has a positive impact on wages, a number of studies indicate small negative effects. It is not clear what drives these differences in estimated wage premia across studies. They may reflect differences in country characteristics or the nature of FDI, as well as differences in methodology. Moreover, the effect of controlling for changes in the composition of the workforce on the estimation of foreign wage premia in developing countries (where such premia are believed to be much larger) remains an open question. In order to better understand the implications of these new findings, we provide the first comparable crosscountry evidence for a number of developing and developed countries.

\subsection{The impact of foreign ownership on non-wage working conditions}

Very little is known about the impact of foreign ownership on non-wage working conditions. While the definition of employment conditions differs across studies, the literature appears to suggest that MNEs have a relatively low tendency to export labour practices to their foreign affiliates, tending instead to adapt to local practices (e.g. Almond and Ferner, 2006). Bloom et al. (2009) use survey data on management and work-life balance practices for over 700 medium-sized firms in the US, UK, Germany and France to analyze to what extent US multinationals export certain practices to their affiliates in Europe. The evidence indicates that US MNEs export management practices but not "work-life" balance practices. Freeman et al. (2007) compare labour practices in domestic and foreign affiliates of a single US firm in different countries and also find that US firms adapt their labour practices to host-country conditions to an important extent.

${ }^{10}$ Martins (2010) finds similar results for Portugal. 
The literature suggests a number of reasons why US MNEs might have a low propensity to export labour practices. First, labour practices tend to be embedded in national rules and social norms. For example, the extensive regulation of the labour market in many European countries and the strong role of trade unions may make it difficult or unattractive for US MNEs to export labour practices to Europe (Bloom et al., 2009; Bloom and Van Reenen, 2010). Second, the low propensity of US MNEs to export working practices may also reflect strategic considerations. For example, local affiliates with a domestic market orientation may enjoy a significantly greater degree of discretion about the way human resources are managed than local affiliates that are more export-oriented (Harzing, 2000; Fento-O’Creevy et al., 2008). ${ }^{11}$ Finally, the low propensity of US MNEs to export labour practices may reflect the specific management style of US MNEs and not be representative for MNEs originating from other countries.

There appears to be no systematic evidence on the propensity of MNEs to export labour practices to developing countries. It is therefore not obvious to what extent the results for developed countries carry over to developing countries. On the one hand, enforcement of labour provisions and trade unions tend to be weaker in developing countries, thereby reducing the role of institutional constraints for the foreign affiliates of MNEs to implement the same labour practices they use in OECD countries. On the other hand, labour practices that are socially acceptable in developing countries may not be acceptable to the consumers and investors in developed countries, creating incentives for MNEs from developed countries to export their human-resource practices abroad.

\section{$4 \quad$ Data sources and cross-country comparability}

\subsection{Data sources}

The data used for this paper are drawn from the national administrative systems of five countries.

\section{Brazil}

The main data source is RAIS (Annual Social Information Report), an annual census of all firms and their employees. It contains detailed information for each employee (wages, hours worked, education, age,

\footnotetext{
${ }^{11}$ This may reflect a greater need for coordination in the context of vertical FDI than for horizontal FDI.
} 
tenure, gender, etc) and each firm (industry, region, size, establishment type, etc). ${ }^{12}$ With the establishment identification number it is possible to follow all establishments that file the RAIS survey. Moreover, with the worker's national insurance number, it is possible to follow all workers that remain in the formal sector and to match the workers' characteristics with those of the establishment. Therefore, we can create a panel that matches workers to their establishments and follow each of them over time. The establishment identifier is used to link RAIS with external sources with information on cross-border mergers and acquisitions and foreign ownership (Thomson Financial and ORBIS).

\section{Germany}

Two data sources are used. First, the Institut für Arbeitsmarkt- und Berufsforschung (IAB) Establishment Panel. The IAB panel is an annual survey of approximately 16,000 plants located in both West and East Germany. It covers $1 \%$ of all plants and $7 \%$ of all employment in Germany, and is therefore a sample weighted towards larger plants. The IAB Panel includes information on employment, bargaining arrangements, total sales, exports, investment, wage bill, location, industry, profit level and nationality of ownership. Ownership is defined as either West German, East German, foreign, or public. Complete information on plant ownership is available for all plants only in 2000 and 2004 . The analysis is therefore restricted to those two years only. Second, we use the employment statistics register of the German Federal Office of Labour (Beschäftigtenstatistik). The Beschäftigtenstatistik covers all employees or trainees registered by the social insurance system. Reported daily gross wages are censored at the social security contribution ceiling. The register covers about $80 \%$ of employees in West Germany and about 85\% in East Germany. Information on employees includes basic demographics, start and end dates of employment spells, occupation and industry, earnings, qualifications (school and post-school), and a plant identification number. By using the plant identification number, we can associate each worker with a plant in the panel. Our analysis is based on western Germany (since the eastern German labor market is still in a special transformation process)

\footnotetext{
${ }^{12}$ RAIS is an administrative report filed by all tax registered Brazilian establishments. Since the information may be used for investigation about labour legislation compliance, firms that do not comply with it do not file in RAIS. Thus, this data set can be considered a census of the formal Brazilian labour market (State-owned enterprises, public administration and non-profit organizations are also required to file the report). Firms that do not provide accurate information will be committing an offense sanctioned by law, a threat that is likely to lead to very high standards of data quality.
} 


\section{Portugal}

The analysis draws on a large matched employer-employee data set, Quadros de Pessoal (Personnel Records), a compulsory survey conducted annually by the Ministry of Employment of all firms located in Portugal with at least one employee. Quadros de Pessoal provides detailed information on all workers in each firm including gender, education, tenure, wages and hours worked, and their firms including foreign ownership, sales, industry and region. ${ }^{13}$ There is also a unique identifier for each firm and individual that allows one to follow firms and individuals through time.

\section{United Kingdom}

The analysis makes use of the Business Structure Database (BSD) and Annual Survey of Hours and Earnings (ASHE). The BSD is a series of annual snapshots from the Inter-Departmental Business Register (IDBR), a live register of UK businesses maintained by the ONS, containing information on employment, sales, foreign ownership, industry and regions as well as a unique enterprise reference number. The ASHE is a $1 \%$ random sample of employees with detailed information on pay and hours of work and can be linked to the BSD using the enterprise reference number.

\section{Indonesia}

The analysis makes use of the Indonesian Census of Manufacturing (Survei Manufaktur), which is conducted annually by the National Statistical Office (BPS). The data include all manufacturing plants with more than 20 employees. Linked worker-firm data are not available, and therefore Indonesia can only be included in the firm-level analysis.

\subsection{Cross-country comparability}

Table 2 summarises information on the various data sources in order to get a sense of their comparability across countries. The main focus is on the four countries for which linked employer-employee data are available. The datasets differ along three key dimensions: the sampling methodology, the unit of observation and coverage. The sampling methodology may in turn differ in terms of the sampling frame and the sampling method. One can distinguish two types of sampling frames (Vilhuber 2007): workerbased sample frames and firm-based sample frames. The German data present an example of a firm-based

\footnotetext{
${ }^{13}$ Particular care is placed on the reliability of the information, as that is used by the Ministry of Employment for the purpose of checking the employer's compliance with labour law.
} 
sample, where we have a sample of firms for which all (or most) workers can be identified. The UK data is a worker-based sample in the sense that for a fraction of the workforce all employers can be identified. In addition to the sampling frame, the data sources may also differ in terms of the sampling method that is used to sample individual units from the sampling frame. The German data are an example of a nonrandom size-weighted sample. The UK data, by contrast, include a $1 \%$ random sample of all employees.

\section{[Insert Table 2]}

Differences in the sampling frame affect the extent to which specific issues can be appropriately analysed in different countries, and as a result, affect the scope for cross-country analysis. Worker-based samples are appropriate for the analysis of worker outcomes, but may be ill-suited for the analysis of firm outcomes. For example, worker-based samples can be usefully employed to analyse the effects of globalisation (including foreign ownership) for individual workers, but are less adequate for the analysis of worker composition for firm outcomes (worker turnover or skill composition). The main drawback of firm-based samples is that it reduces the ability to analyse worker movements across establishments. This is due to the fact that in firm-based samples the probability that a worker switches from a firm in the sample to another firm in the sample depends on the sample size of firms. It is possible therefore that the German sample is not appropriate for the analysis of foreign ownership based on worker movements due to the relatively small number of worker movements between establishments in the sample.

In addition to sample-based data, some data sources include the entire universe of (formal sector) firms and workers. The data for Brazil and Portugal are examples of this. Such data are ideal in the sense that they are not subject to any a priori limitations due to the characteristics of the sampling methodology. Unfortunately, data such as these are only available for a very limited number of countries.

The cross-country comparability of the analysis may further be impaired due to differences in the unit of observation. The analysis for the UK is conducted at the level of the firm (or "enterprise"), whereas the analysis for Germany is necessarily conducted at the level of the plant (or "establishment”). The analysis for Brazil and Portugal can, in principle, be conducted at either level. These differences create differences in firm-size statistics and may also have implications for the definition of foreign ownership.

Finally, the various samples may differ in terms of their coverage across sectors and over time. The data for Brazil, Portugal, Germany and the UK include all market sectors. The data for Indonesia only span the manufacturing sector. The data for Portugal and the United Kingdom broadly span the same time period, whereas the years covered in the German data is more limited. 


\subsection{Descriptive statistics}

In this sub-section, we briefly discuss a number of descriptive statistics with the aim of both illustrating potential problems related to the cross-country comparability of the results, and to preview the econometric analysis in the next section.

Table 3 reports summary statistics on log wages at the individual and plant-level by ownership status and country. ${ }^{14}$ The table shows that, as one would expect, wages in foreign-owned firms are higher, on average, than those in domestic firms. However, these comparisons do not reveal whether these wage differences are due to differences in the composition of the workforce, the characteristics of foreign and domestic firms or ownership status per se. Moreover, average differences might hide differences in the distribution of wages across foreign and domestic firms. For example, foreign-owned firms may provide larger wage differentials for skilled than unskilled workers.

The econometric analysis will focus on the wages of individuals whose employer changes ownership status, or who move between employers of different ownership status, relative to a control group. Table 4 reports the number of ownership changes in the sample for each treatment and country.

The number of firms that change ownership status as a result of cross-border takeovers tends to be substantial except in Germany (due to the use of just two years and the nature of the sample) and Brazil in the case of domestic takeovers of foreign firms. As the number of domestic takeovers of foreign firms was less than 10 in Brazil, this case was dropped from the analysis for this country. At the worker level, changes in ownership as a result of cross-border takeover are much larger as each takeover affects the entire workforce in the target firm. The proportion of workers who work in a domestic firm which is acquired by a foreign firm (1\%-6\%) is higher than the proportion who work for a foreign firm that is acquired by a domestic firm $(0.6 \%-1.9 \%) .{ }^{15}$

The number of individuals who move between domestic and foreign-owned firms is generally smaller than that of individuals who change ownership status as a result of takeovers, but relatively large compared to the actual number of cross-border takeovers. In the UK, about $1 \%$ of all employees in the sample switches from a domestic to foreign firm and $0.7 \%$ change from a foreign to a domestic firm. In Portugal, $0.7 \%$ of

\footnotetext{
${ }^{14}$ Worker-level information is not available for Indonesia.

15 The shares are largest for Germany in both cases. This is likely to reflect in part the size-weighted sample of the German data.
} 
all employees move from a domestic to foreign-owned firm and $0.5 \%$ from foreign-owned to domestic. In the samples for Brazil and Germany, worker movements between foreign-owned and domestic firms tend to be less common. The relatively small number of job movers in the Brazilian reflects the relatively small size of the "foreign sector" in our data, while for Germany this reflects the firm-based nature of the sample.

\section{[Insert Table 4]}

\section{$5 \quad$ Methodology}

Four different changes in ownership status (“treatments") will be considered: foreign takeovers of domestic firms; domestic takeovers of foreign firms; workers who change jobs from domestic to foreign employers; and finally, workers who change jobs from foreign to domestic employers. Each treatment will be evaluated at a point in time less than 12 months after the change in ownership status occurs $(t=0)$, one to two years after the change in ownership status $(t=1)$, and two to three years after the change in ownership status at $(t=2){ }^{16}$

The analysis of cross-border takeovers $(T)$ involves comparing workers who stay in a firm that does not change ownership status with workers who stay in a firm that changes ownership status.

$$
T_{i}^{T}=\left\{\begin{array}{l}
0 \text { if } F_{j, t=-1}=F_{j, t \geq 0} \\
1 \text { if } F_{j, t=-1} \neq F_{j, t \geq 0}
\end{array}\right.
$$

where $T$ refers to treatment status of worker $i, F$ to ownership status of firm $j$, and $t$ to time relative to the year in which the change in $F$ occurs. The analysis of worker movements $(M)$ involves comparing workers who stay in a firm that does not change ownership status with workers who switch to another firm with different ownership status.

$$
T_{i}^{M}=\left\{\begin{array}{l}
0 \text { if } F_{j, t=-1}=F_{j, t \geq 0} \\
1 \text { if } F_{j, t=-1} \neq F_{k \neq j, t \geq 0}
\end{array}\right.
$$

\footnotetext{
${ }^{16}$ Note that because we have annual panel data, the precise date of change of ownership is not known.
} 
We use the method of propensity-score matching (PSM) in combination with difference-in-differences. PSM involves constructing treated and control groups ex post using the observable characteristics of firms and workers before the change in F occurs. Like OLS, PSM provides estimates of the causal impact if selection into the treatment is on the basis of the observed covariates used in the propensity model. The mean difference in outcomes between the treated and untreated gives the average treatment effect on the treated. Formally, this can be written as follows:

$$
\hat{\alpha}_{\text {ATT }}=E\left(y^{1} \mid T=1\right)-E\left(y^{0} \mid T=0\right)
$$

where the superscripts 0 and 1 refer to untreated and treated firms, respectively, $T$ is the dummy for treatment status and $y$ is the outcome of interest.

The propensity score is estimated with a Probit model which specifies the probability of changing ownership status as a function of industry, region and skill dummies, log employment, log average wage, log individual wage, a gender dummy, age, age squared and tenure. All these variables are measured at $t=-1$, the year before $F$ changes. For case $1 \mathrm{~B}$, we also include firm characteristics at $t=0$ to control for the characteristics of the new employer in addition to the old employer. Treated individuals are matched to their untreated counterparts using one-to-one nearest-neighbour matching which attributes a weight of one to the nearest untreated neighbour of each treated observation and zero to others. The estimation of the propensity score and the matching procedure are conducted separately for each year, broad industry (manufacturing or services) and skill group (unskilled, semi-skilled and skilled).

Propensity-score matching is complemented with the difference-in-differences (DiD) estimator, following Heckman et al. (1997). The DiD-estimator controls for any pre-existing constant differences in the outcome variable before the change in ownership, even if those differences are caused by unobservable attributes. The actual regressions are estimated with (firm or worker) fixed effects, which represent a generalisation of DiD. The sample is restricted to individuals that are present each year of relative time period $t=-1$ to $t=2$. In order to avoid conflating treatment and composition effects related to the appearance pattern of individuals, each cohort is balanced.

Using the matched sample of treated and controls the following model is estimated:

$$
y_{i t}=a_{i}+\sum_{t=0}^{2} \gamma_{t} T_{i} D_{t}+\sum_{t=0}^{2} \delta_{t} D_{t}+\varepsilon_{i t}
$$


where $a_{i}$ is a fixed effect for individual $i, \gamma_{t}$ refers to the treatment effect at relative time $t, T_{i}$ is a treatment dummy, $\delta_{t}$ refers to the effect of relative time, $D_{t}$ is a relative time dummy and $\varepsilon_{i t}$ represents a white noise term.

One drawback of Equation (3) is that it takes only account of the effects of ownership changes up to three years after the event. To the extent that the positive effects of ownership changes take time to materialize, the DiD results may not capture the full effect of foreign ownership. For this reason, it is worth complementing the DiD results with simple level comparisons between foreign and domestic firms that control for observable characteristics. While these comparisons may provide upward biased estimates of foreign-domestic differences in employment conditions, they are also more likely to capture the long-term effects of foreign-owned firms on domestic labour markets. These results may thus be interpreted as giving an upper bound on the long-term effects of foreign ownership on employment conditions.

\section{$6 \quad$ Results}

In this section the empirical evidence on the effects of foreign ownership will be presented. Section 6.1 focuses on the effects of cross-border takeovers on average wages using firm-level data, while Section 6.2 reports the estimated effects of cross-border takeovers and worker movements between domestic and foreign firms for individual wages using linked worker-firm data. Section 6.3 considers the effects of foreign takeovers on a range of alternative outcome variables.

\subsection{The average effect of foreign ownership on firm-level wages and employment}

Table 5 presents firm-level evidence using recent data for Germany, Portugal, the UK, Brazil, and Indonesia. The analysis focuses on both the wage and the employment effects of cross-border mergers and acquisitions. The raw differences in average wages and employment between foreign-owned and local firms are large in all of the five countries. Foreign-owned firms pay considerably more on average than local firms, with pay differences varying from 26\% in Germany to 37\% in the UK, 59\% in Portugal, $77 \%$ in Indonesia, and 133\% in Brazil. Foreign-owned firms also employ many more workers than domestic firms, on average, with employment differences ranging from $83 \%$ in Portugal to $200 \%$ in Brazil. This does not necessarily mean that foreign-owned firms provide more and better jobs than comparable domestic firms, but these raw differences are still a potentially important policy consideration. If foreignowned firms are the result of setting up new businesses ("greenfield investment"), then the fact that they are larger and pay higher wages than the average domestic firm is probably relevant to policy-makers and 
workers. On the other hand, if foreign firms are acquiring domestic firms then these raw differences are of less interest.

Controlling for observable firm characteristics considerably reduces the average wage and employment differences between foreign-owned and domestic firms, but they still remain sizable. The wage gap ranges from $11 \%$ in Germany to $30 \%$ in the UK, 32\% in Indonesia, 36\% in Portugal and 105\% in Brazil. The employment gap varies from $78 \%$ in Portugal to $87 \%$ in the UK, $107 \%$ in Indonesia, $116 \%$ in Germany and $188 \%$ in Brazil. Of course, these numbers may still be biased upwards because foreign-owned and domestically-owned firms may be different due to the remaining unobserved heterogeneity.

In the two bottom panels of Table 5 we therefore report estimates based on the change in wages and employment following changes in foreign ownership status. This additionally controls for pre-existing fixed differences between different types of firm. Foreign takeovers of domestic firms do increase average wages, although the size of the effect varies considerably across countries. The effects range from $3 \%$ in Germany to $5 \%$ in the UK, $8 \%$ in Portugal, $11 \%$ in Brazil, and 19\% in Indonesia, while the effect is positive but only statistically significant at the $10 \%$ level in Germany. These results, the first to use a consistent methodology across countries, confirm previous studies, and demonstrate that the wage premium is larger in less developed economies (see the discussion of the empirical literature in section 3).

There is some evidence that the effects of foreign takeovers on average wages tend to become larger over time. The effects of foreign takeovers after two years tend to be larger than their direct effect immediately after takeovers in all countries for which appropriate data are available, but the picture becomes less neat when taking also account of the impact of takeovers one year after the event. For Brazil, the foreign wage premium increases from $10 \%$ directly after takeover to $16 \%$ after two years; for Indonesia, it increases from $18 \%$ directly after the takeover to $22 \%$ after two years; for Portugal, from $5 \%$ to $8 \%$ and the wage premium increases from $4 \%$ to $5 \%$ in the UK. The increase in the positive effect may reflect the time it takes to transfer technology from parent to affiliate and for employees to accumulate human capital. However, it may also reflect the impact of foreign takeovers on the composition of the workforce or the possibility that wage contracts do not change instantaneously.

Foreign takeovers also tend to raise employment in some of the countries analysed, but not in all. Whereas foreign takeovers appear to reduce employment by about $5 \%$ in the UK, presumably reflecting the process of restructuring that is associated with takeovers, they raise employment by $22 \%$ in Indonesia and $24 \%$ in Portugal. No significant effects are found for Brazil and Germany. The somewhat mixed picture with respect to employment may indicate that takeover-induced technological change may not be neutral with respect to the composition of inputs. A shift in emphasis from labour to capital may offset any potential 
positive employment gains that result from the impact of technology transfer on productivity and the scale of production.

Domestic takeovers of foreign firms generally have a small negative effect on average wages and employment. This suggests that the effects of foreign takeovers of domestic firms and domestic takeovers of foreign firms are qualitatively different. This asymmetry supports the hypothesis that foreign takeovers are accompanied by the transfer of modern production and management practices from the parent to the foreign affiliate.

[Insert Table 5]

\subsection{The average effect of foreign ownership on individual wages}

\subsubsection{Cross-border takeovers}

Table 6 presents new evidence of the effects of cross-border mergers and acquisitions on individual wages using linked employer-employee data for Brazil, Germany, Portugal and the United Kingdom.

\section{[Insert Table 6]}

Simple comparisons across workers in foreign-owned and domestic firms reveal significant differences in individual wages ranging from about $10 \%$ in Germany, $20 \%$ in the UK, $25 \%$ in Portugal and $70 \%$ in Brazil. Controlling for observable worker and firm characteristics reduces individual pay differences between workers in foreign-owned and domestic firms, but they remain fairly large. The wage gap varies from $4 \%$ in Germany to $12 \%$ in Portugal and the UK and 23\% in Brazil. Due to the roles of worker and firm selection these estimates may be expected to be upward biased. One can address these problems by focusing on the short-term effects of changes in ownership status due to cross-border mergers and acquisitions. Despite the biased nature of these conditional cross-sectional comparisons, they are still interesting as they provide a useful upper bound on the average effect of foreign ownership by also capturing the effects of greenfield investments and the longer-term effects of foreign ownership, which may be more positive than the short-term effects of cross-border takeovers alone.

Foreign takeovers of domestic firms tend to have a small positive or zero effect on the individual wages of workers who stay in the same firm relative to similar workers who stay in domestic firms that are not taken over in developed countries. The results suggest zero effect in the UK and a small positive effect for Brazil, Germany and Portugal of $1 \%, 3 \%$ and $4 \%$, respectively. The absence of a positive effect in the UK 
may reflect the relative flexibility of the UK labour market compared with Germany and Portugal that makes it hard to sustain differences in pay for identical workers across firms. ${ }^{17}$

The time-profile of the effects of foreign takeovers on individual wages differs across countries. The results for Brazil indicate an instantaneous positive effect of $4 \%$, then turn negative and end with a positive effect of $0.4 \%$ two years after the takeover. For Portugal, the foreign wage premium increases from $2 \%$ directly after the takeover to $5 \%$ after two years. The effects of domestic takeovers of foreign firms on individual wages are also mixed: positive in Germany (0.5\%), negative in Portugal (-4\%) and insignificant in the United Kingdom.

\subsubsection{Worker movements}

In order to identify the effect of foreign ownership for individual wages, the subsequent analysis exploits worker movements between domestic and foreign-owned firms. The results are reported in Table 7. The results indicate wage gains for workers who move from domestic to foreign firms and wage losses for workers who move from foreign to domestic firms. As it seems plausible that wage gains reflect mostly voluntary worker movements (quits), whereas wage losses mostly reflect involuntary worker movements (layoffs), this is consistent with the findings presented above that foreign affiliates tend to provide better working conditions and career prospects than comparable domestic firms. It is also interesting to note that the wage gains associated with worker movements from domestic to foreign firms tend to grow with tenure, while evidence with respect to the time-profile of wage losses associated with worker movements from foreign to domestic firms is more mixed. ${ }^{18}$

\section{[Insert Table 7]}

There is some evidence that the human capital that is accumulated in foreign firms can be transferred to domestic firms by workers who move from foreign to domestic firms. Comparing the magnitude of wage gains associated with worker movements from domestic to foreign firms with the wage losses associated with worker movements from foreign to domestic firms gives an idea of the extent to which worker

\footnotetext{
${ }^{17}$ Using the same data but a somewhat different methodology Andrews et al. (2007) also find that foreign takeovers raise individual wages by 3\% in Germany. The results for Portugal differ somewhat from earlier results in Martins (2004) but are in the same range as those reported in Almeida (2007). The differences with Martins (2004), whose study is the most similar to the present one in terms of methodology and set-up can be attributed to the fact that the present analysis controls for lagged wages whereas Martins (2004) did not. The time period and sectoral coverage are also different.

${ }^{18}$ In Portugal, wage losses appear to fall gradually with time, while in Brazil an opposite picture may be observed.
} 
mobility may be a potentially important channel for wage spillovers. To the extent that wage gains are not completely offset by corresponding wage losses, workers may be able to carry with them some of the knowledge that they have accumulated in foreign firms. The results indicate that wage gains are considerably larger than wage losses in each of the four countries analysed. Thus, worker mobility could be an important channel for wage spillovers. ${ }^{19}$

\subsection{The effect of foreign ownership on other wage and working conditions}

So far, the analysis has concentrated on average differences in pay between foreign-owned and domestic firms. However, theory and previous evidence suggest that the effects of foreign takeovers are unlikely to be evenly distributed across workers with different levels of skills. Moreover, foreign ownership may not only affect wage outcomes but also various non-wage working conditions. In the remainder of this section, the attention shifts from average wage effects to a number of alternative dimensions of wage and non-wage working conditions than can be measured in the available data.

\subsubsection{The effect of foreign takeovers on wages of different skill groups}

This sub-section repeats the analysis of foreign takeovers whilst distinguishing between different skill groups. In a first instance, the impact of foreign takeovers on the wages of production and non-production workers will be analysed at the firm-level using data for Brazil and Indonesia. Individual-level data are not available for Indonesia and Brazil is added for comparability? In a second step, a more detailed analysis will be conducted at the level of the individual worker for the countries for which linked employeremployee data are available by distinguishing between workers with low, medium and high levels of skills.

\section{Firm-level results}

The firm-level results for Brazil and Indonesia are reported in Table 8. The results provide some evidence that foreign wage premia may be more important for skilled than for unskilled workers in emerging economies. In Indonesia, estimated foreign wage premia differ considerably across skilled and unskilled workers, being $30 \%$ for the former and $17 \%$ for the latter. ${ }^{20}$ In Brazil, a positive effect of $11 \%$ is found for

\footnotetext{
${ }^{19}$ However, the analysis is limited to the private returns to worker mobility. In order to analyse wage externalities, one would also have to analyse the wage effects of worker mobility on incumbent workers.

${ }^{20}$ These results are of the same order of magnitude as those reported by Lipsey and Sjöholm (2006) who use the same data for a somewhat different time period. They find that foreign takeovers raise production-worker wages by $17 \%$ and non-production workers by $33 \%$.
} 
skilled workers and no significant effect for unskilled workers. However, when looking at the estimated coefficients, there is no clear difference between skilled and unskilled workers in Brazil. While the positive wage gains for skilled workers appear to strengthen over time in both Brazil and Indonesia, the wage gains for unskilled workers in Indonesia may only be temporary.

\section{[Insert Table 8]}

\section{Worker-level results}

Table 9 reports the effects of foreign takeovers of domestic firms on the wages of low-skilled, semi-skilled and high-skilled workers. The results imply important differences across countries with respect to the role of skill in both qualitative and quantitative terms. In the United Kingdom, the results suggest a small negative impact on the wages of low-skilled workers and no effect for semi- and high-skilled workers. By contrast, in Germany and Portugal, the impact of foreign takeovers on wages is positive for all three skill groups and differences across skill groups are modest. If anything, foreign takeovers tend to benefit most workers with medium skills. For Brazil, the results indicate large differences across skill groups with a positive effect for unskilled workers, a smaller but still positive effect for semi-skilled workers and a negative effect for skilled workers. The findings for Brazil differ from the prevailing view in the literature that the effects of foreign ownership tend to be more important for skilled workers and also from different from the firm-level results presented in Table 8. This could indicate that foreign takeovers are also associated with important workforce composition effects within skill groups. However, the worker-level results are not directly comparable with the firm-level results, because skill groups are defined differently.

All in all, there is little evidence that the wage effects of foreign takeovers are more pronounced for more skilled workers as we conjectured in the theory section of this paper. One possible explanation for the limited support for our conjecture in the data may be that the analysis here only focuses on the short-term effects of foreign takeovers, whereas the incentives to offer higher wages to retain skilled workers to prevent firm-specific knowledge from spilling over to the competition may not be very strong in the first three years after the takeover. Other possibility may be that the positive impact of cross-border takeovers is concentrated among a relatively small group of skilled workers such as CEOs and managers as suggested by Heyman et al. (2006) in the case of Sweden.

[Insert Table 9] 


\subsubsection{The effects of foreign ownership on other working conditions}

Table 10 presents results on the impact of foreign takeovers of domestic firms on a number of working conditions other than average pay. These are working hours (weekly working hours for full-time workers), worker turnover (the rate of job separation), union coverage (the presence of a collective agreement) and low pay (the probability of receiving a wage equal or lower than the minimum wage).

\section{Hours of work}

Raw comparisons between foreign and domestic firms (not reported) suggest that actual working hours are longer in foreign firms in Brazil, Portugal and the UK. ${ }^{21}$ However, this is largely due to specific firm characteristics of firms that are acquired by foreign owners. Foreign takeovers, if anything, have a slight negative impact on working hours. The results are generally not statistically significant and even in Brazil where they are statistically significant, they are economically negligible (i.e. foreign takeover is estimated to reduce working hours by $0.2 \%$, or about 5 minutes per week). A reduction in working hours as a result of foreign takeovers may result when i) foreign takeovers increase hourly earnings and this induces employees to substitute working time for leisure; or ii) when foreign firms are more likely to comply with statutory working hours. In either case, the reduction in working hours is most likely to be perceived positively by workers. $^{22}$

\section{Worker turnover}

There is some evidence that foreign takeovers increase worker turnover in Portugal, while no effect is found in either Brazil or Germany. Increased worker turnover, in principle, may reflect the process of restructuring that accompanies such takeovers in the short-term. It may also result from the possibility that foreign-owned firms have higher worker turnover than domestic firms in the longer-term. Level

${ }^{21}$ In Germany, for which actual hours of work are not available and standard hours are used instead, there is no difference between foreign and domestic firms. This may reflect the fact that in Germany sectoral collective agreements have a major influence over standard working hours (Lee et al., 2007).

${ }^{22}$ The relationship between foreign ownership and hours of work is complicated as one needs to take account of the relationship between ownership and both employee and employer preferences over hours of work. Neither is clear. To the extent that foreign takeovers increase hourly earnings, they either increase or decrease employee preferences over hours of work: employees may desire to work more because the 'cost' of not working increases, but it is equally possible that they wish to work less when their income increases. Employer preferences over working hours may change when MNEs are more likely to comply with national labour provisions than domestic firms: labour provisions that increase the cost of employment (such as employment protection legislation) may be expected to increase preferences for long working hours and statutory regulation of working hours may decrease preferences for long working hours. Foreign and domestic firms may also differ in the extent to which they wish to allow for greater flexibility in working hours in an effort to reduce worker turnover. 
comparisons between domestic and foreign firms suggest that foreign-owned firms experience higher worker turnover also in the longer term (not reported). A possible explanation for this may be that foreignowned firms have more elastic labour demand as they more easily substitute local workers for workers in other locations in response to changes in relative wages (Fabbri et al. 2003; Barba-Navaretti et al. 2003; Hijzen and Swaim, 2010).

\section{Union coverage}

In the UK, foreign takeovers appear to reduce the probability of being covered by a collective agreement. This may indicate that foreign firms are less likely to engage in collective agreements or that foreign MNEs in the UK originate from countries where collective agreements are less common. Foreign takeovers in Germany do not appear to have an impact on the probability of being covered by a multi-firm collective agreement or a single-firm collective agreement relative to no collective agreement. Given the importance of collective agreement in employer-employee relations in Germany the absence of a significant effect does not seem surprising.

\section{Low pay}

While individuals in foreign-owned firms are less likely to earn the minimum wage (or less) than those in domestic firms (not reported), ${ }^{23}$ foreign takeovers appear to increase the probability in Brazil and Portugal of employees earning the minimum wage or less relative to comparable workers in firms that are not taken over, but there is no such effect in the United Kingdom. Note that in Brazil and Portugal, this does not necessarily mean that workers are worse off in absolute terms, but that workers in the bottom-end of the wage distribution do not experience as much wage growth as they would have done had their firm not had been taken over by a foreign owner.

\section{[Insert Table 10]}

\footnotetext{
${ }^{23}$ This indicates that foreign firms employ on average fewer low-pay workers than domestic firms.
} 
Until recently the empirical literature on the role of foreign ownership on wages was characterised by a consensus that foreign-owned firms pay higher wages than domestic firms and that foreign-wage premia are particularly important in emerging economies. This consensus was to a large extent based on evidence that identifies the role of foreign ownership on average wages by focusing on cross-border takeovers using longitudinal firm-level data. This paper provides three sets of findings that help to sharpen and qualify the consensus in the literature.

First, this paper replicates the evidence on which the consensus is based by applying a standardised methodology to firm-level data for three developed countries and two large emerging economies. The results confirm that foreign-owned firms offer higher average wages than their domestic counterparts in all five countries. Moreover, consistent with the conventional wisdom, foreign-wage premia appear to be particularly important in emerging economies. Foreign-wage premia in the three developed countries are consistently below $10 \%$ (between $3 \%$ and $8 \%$ ) and foreign-wage premia in the two emerging economies in the range of $10 \%$ and $20 \%$.

Second, this paper shows that the conventional wisdom may be overstating the true wage premium. We apply a standardised methodology to analyse the effects of cross-border takeovers using linked workerfirm data for three developed countries and one large emerging economy. Foreign wage premia are much smaller than previously believed: foreign-wage premia are less than $4 \%$ in all the four countries analysed and may even disappear altogether. Moreover, there is no longer any indication that foreign-wage premia are more important in emerging economies, although one should be careful in drawing strong conclusions as the worker-level analysis only involves one emerging economy. To the extent that foreign takeovers lead to changes in the skill composition in favour of more skilled workers, this may indeed imply that the foreign-wage premia found in firm-level studies are largely spurious. However, to properly assess the implications of the recent worker-level evidence on the effects of cross-border takeovers on wages, it is important to understand what lies behind the compositional changes in the workforce that appear to be associated with cross-border takeovers.

Third, this paper shows - using the same standardised methodology as for takeovers for four countries - that foreign-wage premia associated with worker movements from domestic to foreign firms may be economically important and that such movements may be more beneficial for workers in less developed countries (in the order of $5 \%$ to $10 \%$ for the three developed countries and over $20 \%$ in Brazil). Moreover, to the extent that substantial wage differences between similar workers within firms may be hard to sustain 
one would expect the positive effects of foreign ownership to new hires to trickle down to the rest of the workforce with time. The results on worker mobility further suggest that compositional changes in the workforce as a result of entry of new workers and exit of incumbent workers may also account for some of the observed differences in foreign wage premia in firm-level studies of cross-border takeovers and worker-level studies that restrict the sample to incumbent workers.

While this is not the first paper to show that foreign-wage premia become much smaller once one controls for changes in the composition of the workforce, or to look at the role of foreign ownership in the context worker movements, this study is much more comprehensive in providing comparable results using a standardised methodology to analyse both cross-border takeovers and worker movements for four different countries. As a result, it provides a substantially better basis for assessing the implications of various worker-level studies for the conventional wisdom.

Altogether, our reading from the present results is that one should be careful not to exaggerate the potential positive effects of foreign direct investment on workers abroad, but that there is as of yet no sufficient basis for adjusting the conventional wisdom qualitatively. The main reason for remaining loyal to the conventional view - for the moment - is that the new evidence on foreign takeovers is based on a arguably quite narrow aspect of foreign direct investment by restricting itself to the short-term effects of foreign takeovers to incumbents workers. The conditional cross-sectional comparisons of average wages between domestic and foreign firms provide some suggestive evidence that the effects of foreign ownership could be more positive, particularly in emerging economies, in the longer term; for newly hired workers; or for workers in "Greenfield" investments.

This paper further contributes to the literature by going beyond average wages by studying the role of foreign ownership for the wages of different groups of workers as well as for non-wage working conditions. As this is relatively unchartered territory, the results with respect to this part of the analysis are much more tentative. While we hypothesised that the wage effects of foreign ownership are likely to be more pronounced for more skilled workers, the evidence for this in the paper is mixed. Although the firmlevel evidence tends to be in line with the conjecture, the more detailed analysis at the worker-level suggests that distributional effects may differ importantly across countries. Possible explanations for these mixed results may relate to the short horizon of the takeover analysis, which may not be long enough to accumulate important firm-specific knowledge and thus to create incentives to offer higher wages, or the relatively crude definition of skill used in this paper. From the analysis of other non-wage working conditions, one may draw the following tentative conclusions. First, the evidence that foreign takeovers affect working conditions other than average wages is considerably weaker than that in the context of 
average wages. Second, in contrast to average wages, the impact of foreign takeovers on other working conditions is not unambiguously positive. Third, there is little evidence to suggest that MNEs export working conditions abroad. While foreign takeovers may have some impact on non-wage working conditions, it is not clear whether these effects derive from a centralised policy or reflect the rational response by foreign-owned firms to local conditions. 


\section{References}

Aitken, B., A. Harrison and R.E. Lipsey (1996), "Wages and foreign ownership A comparative study of Mexico, Venezuela, and the United States" Journal of International Economics, vol. 40(3-4), pp 345-371.

Aitken, B. and A.E. Harrison (1999), "Do Domestic Firms Benefit from Direct Foreign Investment? Evidence from Venezuela”, American Economic Review, Vol. 89, No. 3, pp. 605-618.

Almeida, R. (2007), “The Effects of Foreign Owned Firms on the Labor Market”, Journal of International Economics 72(1) pp. 75-96.

Almond, P. and A. Ferner (2006), American Multinationals in Europe, Oxford: Oxford University Press.

Andrews, M., L. Bellmann, T. Schank and R. Upward (2007), "Foreign-owned plants and job security", GEP Research Paper, 2007/36.

Andrews, M., L. Bellmann, T. Schank and R. Upward (2009), “The Takeover and Selection Effects of Foreign Ownership in Germany: An Analysis Using Linked Worker-Firm Data”, Review of World Economics 142(2) pp. 293-317.

Balsvik, R. (2006), "Is Mobility of labour a channel for spillovers from multinationals to local domestic firms?” Norwegian School of Economics, mimeo.

Barba-Navaretti, G., D. Checchi and A. Turrini, (2003), “Adjusting Labour Demand: Multinationals vs. National Firms. A Cross-European Analysis”, Journal of the European Economic Association, 1(23), pp. 708-719.

Bloom, N., T. Kretschmer and J. Van Reenen (2009), "Work Life Balance, Management Practices and Productivity”, in R. Freeman and K. Shaw (eds.), International Differences in Business Practices and the Productivity of Firms, NBER: University of Chicago.

Bloom, N. and J. Van Reenen (2010), "Why do management practices differ across firms and countries?”, Journal of Economic Perspectives, Spring 2010.

Decreuse, B. and P. Maarek (2007), "Foreign direct investment and the labour share in developing countries”, mimeo, University of Aix-Marseilles II.

Earle, J.S. and A. Telegdy (2007), “Ownership and Wages: Estimating Public-Private and ForeignDomestic Differentials with LEED from Hungary, 1986-2003”, NBER Working Paper, No. 12997.

Egger, H. and U. Kreickemeier (2009), “Why Foreign Ownership may be Good for You”, mimeo.

Fabbri, F., J.E. Haskel and M.J. Slaughter (2003), "Does Nationality of Ownership Matter for Labor Demands?”, Journal of the European Economics Association, 1(2/3) pp. 698-707.

Fento-O'Creevy, M.P., P. Gooderham, and O. Nordhaug (2008), "HRM in US subsidiaries in Europe and Austraila: centralisation or autonomy?”, Journal of International Business Studies, 39(1) pp. 151166. 
Fosfuri, A., M. Motta and T. Rønde (2001), "Foreign Direct Investment and Spillovers through Workers' Mobility”, Journal of International Economics, Vol. 53, pp. 205-222.

Freeman, R., D. Kruse and J. Blasi (2007), “The Same Yet Different: Worker Reports on Labour Practices and Outcomes in a Single Firm across Countries”, NBER Working Paper, No. 13233.

Girma, S. and H. Görg (2007), "Evaluating the foreign ownership wage premium using a difference-indifferences matching approach", Journal of International Economics 72(1) pp. 97-112.

Glass, A.J. and K. Saggi (2002), "Multinational Firms and Technology Transfer”, Scandinavian Journal of Economics, Vol. 104, pp. 495-513.

Goldberg, P. and N. Pavcnik (2007), "Distributional Effects of Globalization in Developing Countries," Journal of Economic Literature 45(1) pp. 39-82.

Harrison, A.E. and J. Scorse (2010), "Multinationals and Anti-sweatshop Activism," American Economic Review, Vol. 100(1), pp. 247-273.

Harzing, A .W. (2000), "An empirical analysis and extension of the Bartlett and Ghoshal typology of multinational companies”, Journal of International Business Studies 31(1) pp. 101-120.

Heckman, J., H. Ichimura and P. Todd (1997), "Matching as an econometric estimator: Evidence from evaluating a job training programme”, Review of Economic Studies 64(4) pp. 605-654.

Heyman, F., F. Sjöholm and P. Gustavsson Tingvall (2006), “Acquisitions, Multinationals and Wage Dispersion”, RIIE Working Paper, No. 675.

Heyman, F., F. Sjöholm and P. Gustavsson Tingvall (2007), "Is there Really a Foreign Ownership Wage Premium? Evidence from Matched Employer-Employee Data”, Journal of International Economics 73(2) pp.355-376.

Hijzen, A., and P. Swaim (2010), “Offshoring, Labour Market Institutions and the Elasticity of Labour Demand”, European Economic Review, forthcoming.

Huttunen, K. (2007), “The Effect of Foreign Acquisition on Employment and Wages: Evidence from Finnish Establishments”, Review of Economics and Statistics 89(3) pp.497-509.

Lee, S.., D. McCann and J.C. Messenger (2007), Working Time Around the World. Trends in Working Hours, Laws and Policies in a Global Comparative Perspective, Oxon and New York: Routledge.

Lipsey, R.E and F. Sjöholm (2004), "Foreign Direct Investment, Education, and Wages in Indonesian Manufacturing”, Journal of Development Economics 73(1) pp.415-422.

Lipsey, R.E and F. Sjöholm (2006), "Foreign Firms and Indonesian Manufacturing Wages: An Analysis with Panel Data”, Economic Development and Cultural Change 55(1) pp.201-221.

Malchow Møller, N., J. Markusen and B. Schjerning (2007), "Foreign Firms, Domestic Workers”, NBER Working Paper, No. 13001.

Martins, P. (2004), “Do Foreign Firms Really Pay Higher Wages? Evidence from Different Estimators”, IZA Discussion Paper 1388. 
Martins, P.S. (2010), "Paying More to Hire the Best? Foreign Firms, Wages and Worker Mobility", Economic Inquiry, forthcoming.

Martins, P.S. and Y. Yong (2010), "Globalised labour markets? International rent sharing across 47 countries”, IZA Discussion Paper, forthcoming.

Moran, T. H. (2006), "Harnessing Foreign Direct Investment for Development: Policies for Developed and Developing Countries”, Washington DC: Center for Global Development.

Morrisey, O. and D.W. Te Velde (2003), "Do Workers in Africa Get a Wage Premium if Employed in Firms Owned by Foreigners?', Journal of African Economies 12(1), pp.41-73.

OECD (2007), “OECD workers in a global economy: Increasingly vulnerable?”, OECD Employment Outlook, Paris: OECD.

Pissarides, C. (2009), “The Unemployment Volatility Puzzle: Is Wage Stickiness the Answer?”, Econometrica, Vol. 77, pp. 1339-1369.

Rosenbaum, P. and D. Rubin (1983), "The Central Role of the Propensity Score in Observational Studies for Causal Effects”, Biometrika, 70(1) pp. 41-55.

Vilhuber, L. (2007) “Adjusting imperfect data: overview and case studies”, NBER Working Paper, No. 12977. 
Table 1. An overview of the literature on foreign wage premia

Study Country Sample $\quad$ Treatment $^{a}$ Main findings $^{2}$

\section{Cross-sectional studies}

Aitken, Mexico, Harrison and United States,

Lipsey (1996) Venezuela

1984-1990; 1987;

1977-1989,

manufacturing

Foreign-

owned

Positive and significant wage differences for Mexico and Venezuela after controlling for plant size, geographic location, skill mix and capital intensity, but not in the United States.

\begin{tabular}{|c|c|c|c|}
\hline $\begin{array}{l}\text { Morrisey and } \\
\text { Te Velde } \\
\text { (2003) }\end{array}$ & $\begin{array}{l}\text { Cameroon, } \\
\text { Ghana, Kenya, } \\
\text { Zambia, } \\
\text { Zimbabwe }\end{array}$ & $\begin{array}{l}\text { Pooled cross-sections } \\
\text { for various years } \\
\text { during 1990-1993, } \\
\text { manufacturing }\end{array}$ & $\begin{array}{l}\text { Foreign- } \\
\text { owned }\end{array}$ \\
\hline $\begin{array}{l}\text { Sjöholm and } \\
\text { Lipsey (2004) }\end{array}$ & Indonesia & 1996, manufacturing & $\begin{array}{l}\text { Foreign- } \\
\text { owned }\end{array}$ \\
\hline
\end{tabular}

II. Longitudinal studies ( Firm-fixed effect)s

$\begin{array}{lll}\begin{array}{l}\text { Almeida } \\ \text { (2007) }\end{array} & \text { Portugal } & \begin{array}{l}1991-1998, \\ \text { manufacturing }\end{array} \\ \begin{array}{l}\text { Conyon, } \\ \text { Girma, } \\ \text { Thompson, and } \\ \text { Wright (2002) }\end{array} & \begin{array}{l}\text { United } \\ \text { Kingdom }\end{array} & \begin{array}{l}1989-1994, \\ \text { manufacturing }\end{array} \\ \begin{array}{l}\text { Earle and } \\ \text { Telegdy (2007) }\end{array} & \text { Hungary } & 1986-2003 \\ \begin{array}{l}\text { Görg and } \\ \text { Girma (2007) }\end{array} & \text { United } & \begin{array}{l}1980-1994, \\ \text { manufacturing }\end{array} \\ & \text { Kingdom } & \\ \begin{array}{l}\text { Huttunen } \\ \text { (2007) }\end{array} & \text { Finland } & \begin{array}{l}1988-2001, \\ \text { manufacturing }\end{array} \\ & & \\ \begin{array}{l}\text { Sjöholm and } \\ \text { Lipsey (2006) }\end{array} & \text { Indonesia } & \begin{array}{l}1975-1999, \\ \text { manufacturing }\end{array}\end{array}$

Foreign Foreign takeovers have a small positive effect of 2takeovers $4 \%$ on average wages.

Takeovers, Cross-border takeovers have small positive effect of asymmetric $3.3 \%$ on average wages.

Takeovers, symmetric

Cross-border takeovers have a positive effect of $7 \%$ on average wages.

Foreign takeovers

Takeovers of UK firms by US firms increases the wage of both skilled and unskilled workers (4-13\%), but takeovers by non-UK EU firms do not.

Foreign takeovers

Takeovers, asymmetric
Foreign takeovers have a positive effect on wages. The wage increase occurs within one to three years from the acquisition.

Foreign takeovers have a positive effect of $10 \%$ on the average wage of blue-collar workers and $21 \%$ on the average wage of white-collar workers. 
Table 1. An overview of the literature on foreign wage premia (cont'd)

\begin{tabular}{|c|c|c|c|c|}
\hline Study & Country & Sample & Treatment ${ }^{a}$ & Main findings \\
\hline \multicolumn{5}{|c|}{ III. Longitudinal studies - Worker and firm fixed effects } \\
\hline $\begin{array}{l}\text { Andrews, Bellman, } \\
\text { Schank and } \\
\text { Upward (2009) }\end{array}$ & $\begin{array}{l}\text { West and } \\
\text { East } \\
\text { Germany }\end{array}$ & 2000 and 2004 & $\begin{array}{l}\text { Takeovers and } \\
\text { movers, } \\
\text { asymmetric }\end{array}$ & $\begin{array}{l}\text { For West-Germany foreign takeovers are associated } \\
\text { with } 3 \% \text { increase in individual wage. The effects for } \\
\text { East Germany tend to be insignificant. Movers from } \\
\text { domestic to foreign firms experience an increase in } \\
\text { wages of } 6 \% \text {. }\end{array}$ \\
\hline Balsvik (2006) & Norway & $\begin{array}{l}\text { 1990-2000, } \\
\text { manufacturing }\end{array}$ & $\begin{array}{l}\text { Takeovers and } \\
\text { movers, } \\
\text { asymmetric }\end{array}$ & $\begin{array}{l}\text { Foreign takeovers have a small positive effect of } 3 \% \\
\text { on individual wages. Movers from domestic to } \\
\text { foreign firms experience an increase in wages of } 8 \%\end{array}$ \\
\hline $\begin{array}{l}\text { Heyman, Sjöholm } \\
\text { Gustavsson and } \\
\text { Tinvall (2007a) }\end{array}$ & Sweden & $1996-2000$ & $\begin{array}{l}\text { Takeovers, } \\
\text { symmetric }\end{array}$ & $\begin{array}{l}\text { Foreign takeovers have a small negative effect of } \\
-2 \% \text { on individual wages. }\end{array}$ \\
\hline $\begin{array}{l}\text { Heyman, Sjöholm } \\
\text { and Gustavsson } \\
\text { Tinvall (2007b) }\end{array}$ & Sweden & $1996-2000$ & $\begin{array}{l}\text { Takeovers, } \\
\text { asymmetric }\end{array}$ & $\begin{array}{l}\text { Foreign takeovers increase wages of high-skilled } \\
\text { workers by } 2 \% \text { and reduce wages of medium and } \\
\text { low-skilled workers by } 4 \% \text { and } 6 \% \text {. }\end{array}$ \\
\hline $\begin{array}{l}\text { Malchow-Moller, } \\
\text { Markusen and } \\
\text { Schjening (2007) }\end{array}$ & Denmark & $2000-2002$ & $\begin{array}{l}\text { Takeovers, } \\
\text { symmetric }\end{array}$ & $\begin{array}{l}\text { Foreign takeovers have small positive effect of } 1 \% \\
\text { on individual wages. }\end{array}$ \\
\hline Martins (2004) & Portugal & $\begin{array}{l}\text { 1991-1999, } \\
\text { manufacturing }\end{array}$ & $\begin{array}{l}\text { Takeovers, } \\
\text { symmetric }\end{array}$ & $\begin{array}{l}\text { Foreign takeovers have small negative effect }-3 \% \text { on } \\
\text { individual wages. }\end{array}$ \\
\hline
\end{tabular}

${ }^{a}$ Some studies impose the assumption of symmetry on the treatment. In the present case, this means that the effects of changes in ownership from foreign to domestic and domestic to foreign are assumed to be of the same magnitude but of opposite sign. If this assumption is not imposed but both changes are allowed, the treatment is said to be asymmetric. 
Table 2. National data sources

\begin{tabular}{|c|c|c|c|c|c|}
\hline & Germany & Portugal & United Kingdom & Brazil & Indonesia \\
\hline $\begin{array}{l}\text { Data } \\
\text { sources }\end{array}$ & $\begin{array}{l}\text { Institut für Arbeitsmarkt- und } \\
\text { Berufsforschung (IAB) } \\
\text { Establishment Panel and the } \\
\text { employment statistics register } \\
\text { of the German Federal Office } \\
\text { of Labour } \\
\text { (Beschäftigtenstatistik). }\end{array}$ & $\begin{array}{l}\text { Quadros de } \\
\text { Pessoal or } \\
\text { 'Personnel } \\
\text { Records' } \\
\text { (Ministry of } \\
\text { Employment) }\end{array}$ & $\begin{array}{l}\text { Annual } \\
\text { Respondent's } \\
\text { Database (ARD) for } \\
\text { the firm-level } \\
\text { analysis. Business } \\
\text { Structure Database } \\
\text { (BSD) and Annual } \\
\text { Survey of Hours and } \\
\text { Earnings (ASHE) } \\
\text { for worker-level } \\
\text { analysis. }\end{array}$ & $\begin{array}{l}\text { RAIS, Global } \\
\text { Mergers and } \\
\text { Acquisitions } \\
\text { Database (Thomson } \\
\text { Financial Securities) } \\
\text { and Orbis (Bureau } \\
\text { van Dijk) }\end{array}$ & $\begin{array}{l}\text { Survei Manufaktur, } \\
\text { the Indonesian } \\
\text { Census of } \\
\text { Manufacturing } \\
\text { (Statistical Office, } \\
\text { BPS) }\end{array}$ \\
\hline $\begin{array}{l}\text { Unit of } \\
\text { observation }\end{array}$ & Plant & Firm & Firm & Firm & Plant \\
\hline $\begin{array}{l}\text { Sample } \\
\text { selection }\end{array}$ & $\begin{array}{l}\text { All plants with employees } \\
\text { subject to social security. } \\
\text { Large plants are } \\
\text { oversampled. The sample } \\
\text { comprises about } 1 \% \text { of plants } \\
\text { and } 10 \% \text { of employees. }\end{array}$ & $\begin{array}{l}\text { All firms with at } \\
\text { least one } \\
\text { employee. }\end{array}$ & $\begin{array}{l}\text { The "selected } \\
\text { sample" of the ARD } \\
\text { is a census of firms } \\
\text { with } 250 \text { or more } \\
\text { employees, and a } \\
\text { sample of smaller } \\
\text { firms. The BSD } \\
\text { includes all } \\
\text { enterprises whose } \\
\text { plants are subject to } \\
\text { VAT or social } \\
\text { security. }\end{array}$ & $\begin{array}{l}\text { All firms with at } \\
\text { least one employee. }\end{array}$ & $\begin{array}{l}\text { The census surveys } \\
\text { all registered } \\
\text { manufacturing } \\
\text { plants with more } \\
\text { than } 20 \text { employees. }\end{array}$ \\
\hline $\begin{array}{l}\text { Sectoral } \\
\text { coverage }\end{array}$ & Manufacturing and services & $\begin{array}{l}\text { Manufacturing } \\
\text { and services }\end{array}$ & $\begin{array}{l}\text { Manufacturing and } \\
\text { services }\end{array}$ & $\begin{array}{l}\text { Manufacturing and } \\
\text { services }\end{array}$ & Manufacturing \\
\hline $\begin{array}{l}\text { Time } \\
\text { coverage }\end{array}$ & 2000 and 2004 & $\begin{array}{l}1997-2004 \\
\text { except } 2001\end{array}$ & $1997-2005$ & 1994-2005 & $\begin{array}{l}\text { 1997-2005 except } \\
2001\end{array}$ \\
\hline
\end{tabular}


Table 3: Summary statistics of log wage by ownership status (in national currency)

\begin{tabular}{|c|c|c|c|c|c|c|}
\hline & & Germany & Portugal & $\begin{array}{l}\text { United } \\
\text { Kingdom }\end{array}$ & Brazil & Indonesia \\
\hline \multicolumn{7}{|c|}{ (a) Firm/establishment level } \\
\hline \multirow{3}{*}{ All firms } & $N$ & 3,474 & 146,843 & 78,850 & 156,524 & 74,723 \\
\hline & Mean log wage & 4.351 & 1,464 & 2.921 & 1.964 & 8.408 \\
\hline & S.D. & 0.345 & 0.447 & 0.588 & 0.660 & 0.998 \\
\hline \multirow{3}{*}{ Foreign-owned } & $N$ & 290 & 7,081 & 9,220 & 2,165 & 9,632 \\
\hline & Mean log wage & 4.587 & 2.024 & 3.254 & 3.282 & 9.018 \\
\hline & S.D. & 0.323 & 0.546 & 0.475 & 0.666 & 0.924 \\
\hline \multirow{3}{*}{ Domestic } & $N$ & 3,184 & 139,762 & 69,630 & 154,359 & 65,091 \\
\hline & Mean log wage & 4.33 & 1.436 & 2.877 & 1.945 & 8.318 \\
\hline & S.D. & 0.339 & 0.422 & 0.587 & 0.641 & 0.977 \\
\hline \multicolumn{7}{|l|}{ (b) Worker level } \\
\hline \multirow{3}{*}{ All workers } & $N$ & 397,584 & $6,928,076$ & 441,159 & $12,775,660$ & \\
\hline & Mean log wage & 4.625 & 1.537 & 2.199 & 2.484 & \\
\hline & S.D. & 0.299 & 0.583 & 0.525 & 0.947 & \\
\hline \multirow{3}{*}{$\begin{array}{l}\text { Workers in } \\
\text { foreign-owned } \\
\text { firms }\end{array}$} & $N$ & 87,697 & 984,831 & 78,644 & $2,536,778$ & \\
\hline & Mean log wage & 4.701 & 1.765 & 2.366 & 3.021 & \\
\hline & S.D. & 0.281 & 0.628 & 0.545 & 0.849 & \\
\hline \multirow{3}{*}{$\begin{array}{l}\text { Workers in } \\
\text { domestic firms }\end{array}$} & $N$ & 309,887 & $5,943,245$ & 362,515 & $10,238,882$ & \\
\hline & Mean log wage & 4.604 & 1.499 & 2.162 & 2.351 & \\
\hline & S.D. & 0.3 & 0.567 & 0.513 & 0.922 & \\
\hline
\end{tabular}


Table 4: Foreign ownership changes of workers and firms

\begin{tabular}{|c|c|c|c|c|c|c|c|c|c|c|}
\hline \multirow[t]{2}{*}{ Treatment } & \multicolumn{2}{|c|}{ Germany } & \multicolumn{2}{|c|}{ Portugal } & \multicolumn{2}{|c|}{$\begin{array}{l}\text { United } \\
\text { Kingdom }\end{array}$} & \multicolumn{2}{|c|}{ Brazil } & \multicolumn{2}{|c|}{ Indonesia } \\
\hline & Obs. & $\%$ & Obs. & $\%$ & Obs. & $\%$ & Obs. & $\%$ & Obs. & $\%$ \\
\hline $\begin{array}{l}\text { Foreign takeovers of domestic firms } \\
\text { (number of firms) }\end{array}$ & 36 & 2.13 & 534 & 0.00 & 967 & 1.23 & 117 & 0.01 & 793 & 1.06 \\
\hline $\begin{array}{l}\text { Domestic takeovers of foreign firms } \\
\text { (number of firms) }\end{array}$ & 21 & 1.21 & 254 & 0.04 & 351 & 0.45 & n.a & n.a & 463 & 0.62 \\
\hline $\begin{array}{l}\text { Foreign takeovers of domestic firms } \\
\text { (number of workers) }\end{array}$ & 11,976 & 6.02 & 57,712 & 0.79 & 4,476 & 1.01 & 176,202 & 1.35 & n.a & n.a \\
\hline $\begin{array}{l}\text { Domestic takeovers of foreign firms } \\
\text { (number of workers) }\end{array}$ & 3,754 & 1.89 & 86,751 & 1.19 & 1,182 & 0.27 & 21,541 & 0.16 & n.a & n.a \\
\hline $\begin{array}{l}\text { Workers moving from domestic to } \\
\text { foreign firms }\end{array}$ & 341 & 0.17 & 50,529 & 0.69 & 4,552 & 1.03 & 31,601 & 0.24 & n.a & n.a \\
\hline $\begin{array}{l}\text { Workers moving from foreign to } \\
\text { domestic firms }\end{array}$ & 313 & 0.16 & 39,517 & 0.54 & 3,064 & 0.69 & 19,891 & 0.15 & n.a & n.a \\
\hline
\end{tabular}


Table 5: The effects of cross-border takeovers on average wages and employment: Firm-level evidence Panel a: Average wages

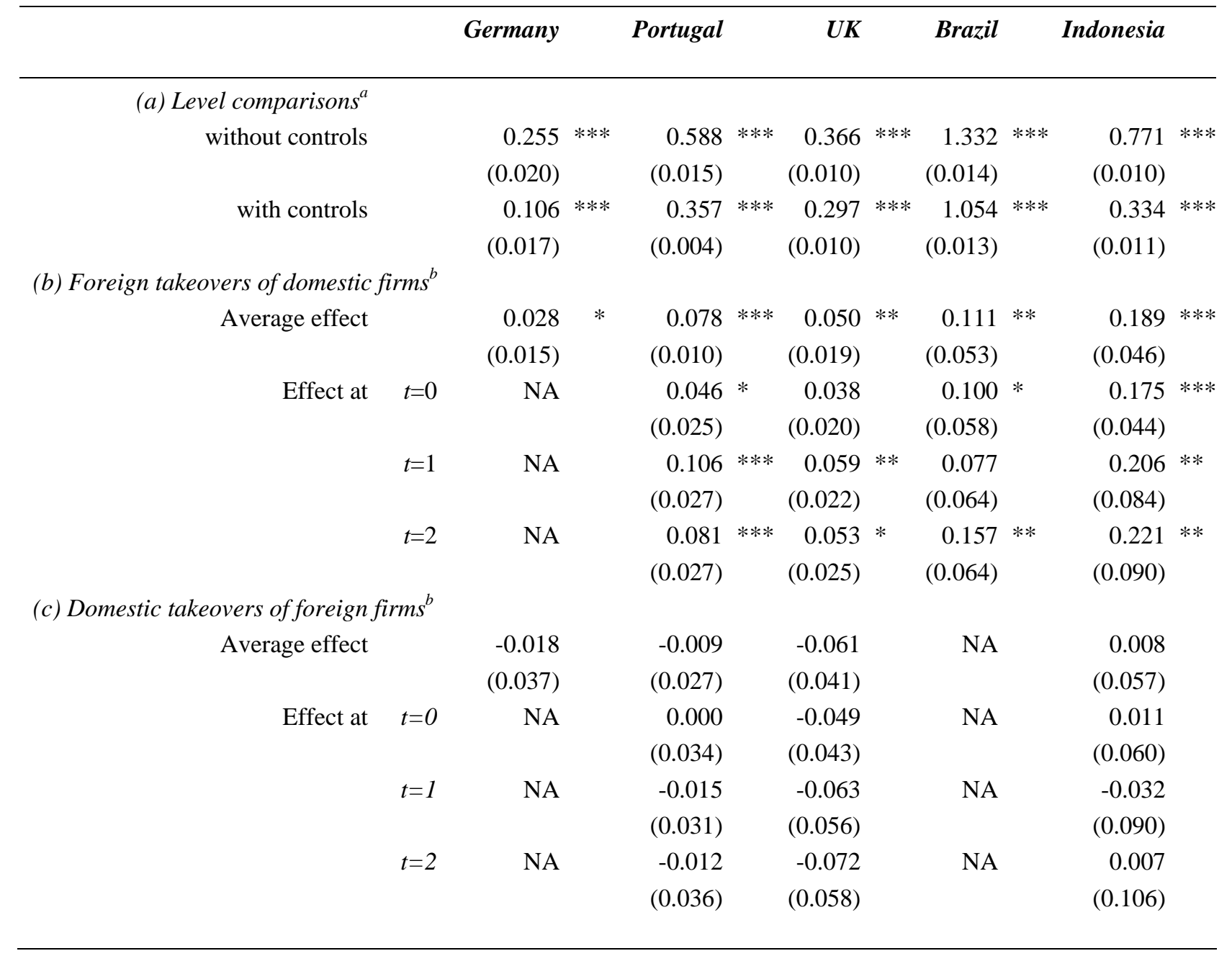


Panel b: Employment

\begin{tabular}{|c|c|c|c|c|c|c|c|c|}
\hline & & Germany & Portugal & & $\begin{array}{r}\text { United } \\
\text { Kingdom } \\
\end{array}$ & Brazil & Indonesia & \\
\hline (a) Level compariso & & & & & & & & \\
\hline without controls & & $1.632 * * *$ & 0.827 & $* * *$ & $0.890 * * *$ & $2.004 * * *$ & 1.244 & $* * *$ \\
\hline & & $(0.102)$ & $(0.011)$ & & $(0.031)$ & $(0.026)$ & $(0.014)$ & \\
\hline with controls & & $1.155^{* * *}$ & 0.776 & $* * *$ & $0.872 * * *$ & $1.875^{* * *}$ & 1.065 & $* * *$ \\
\hline & & $(0.089)$ & .. & & $(0.031)$ & $(0.026)$ & $(0.014)$ & \\
\hline (b) Foreign takeove & $f d o m$ & stic firms ${ }^{b}$ & & & & & & \\
\hline Average effect & & -0.060 & 0.238 & $* * *$ & $-0.047 *$ & 0.140 & 0.220 & $* * *$ \\
\hline & & $(0.097)$ & $(0.061)$ & & $(0.022)$ & $(0.111)$ & $(0.027)$ & \\
\hline Effect at & $\mathrm{t}=0$ & NA & 0.238 & $* * *$ & -0.043 & 0.097 & 0.213 & $* * *$ \\
\hline & & & $(0.066)$ & & $(0.081)$ & $(0.131)$ & $(0.027)$ & \\
\hline & $t=1$ & NA & 0.235 & $* * *$ & $-0.065 * *$ & 0.156 & 0.245 & $* * *$ \\
\hline & & & $(0.064)$ & & $(0.025)$ & $(0.117)$ & $(0.046)$ & \\
\hline & $t=2$ & NA & 0.241 & $* * *$ & -0.034 & 0.167 & 0.247 & $* * *$ \\
\hline & & & $(0.076)$ & & $(0.031)$ & $(0.130)$ & $(0.060)$ & \\
\hline (c) Domestic takeove & of for & ign firms ${ }^{b}$ & & & & & & \\
\hline Average effect & & -0.042 & 0.005 & $*$ & -0.013 & NA & 0.059 & $* *$ \\
\hline & & $(0.165)$ & $(0.097)$ & & $(0.046)$ & & $(0.028)$ & \\
\hline Effect at & $\mathrm{t}=0$ & NA & 0.015 & $* * *$ & 0.014 & NA & 0.001 & \\
\hline & & & $(0.104)$ & & $(0.034)$ & & $(0.052)$ & \\
\hline & $\mathrm{t}=1$ & NA & 0.018 & $* * *$ & -0.015 & NA & 0.073 & \\
\hline & & & $(0.101)$ & & $(0.057)$ & & (0.069) & \\
\hline & $t=2$ & NA & -0.017 & $* * *$ & -0.037 & NA & 5.307 & \\
\hline & & & $(0.120)$ & & $(0.068)$ & & $(0.001)$ & \\
\hline
\end{tabular}

* significant at $10 \%, * *$ significant at $5 \%, * * *$ significant at $1 \%$, confidence interval based on robust standard errors.

${ }^{a}$ Estimations with OLS. Coefficients reflect percentage differences. Controls include log employment, industry and region dummies for the average wage comparisons, and industry and region dummies for the employment comparisons.

${ }^{\mathrm{b}}$ Estimations with difference-in-difference propensity-score matching. Coefficients reflect percentage differences in the average wage and employment between firms that change ownership status relative to their counterfactual value had they remained under domestic ownership. 
Table 6: The effects of cross-border takeovers of domestic firms on individual wages:

Evidence from linked employer-employee data

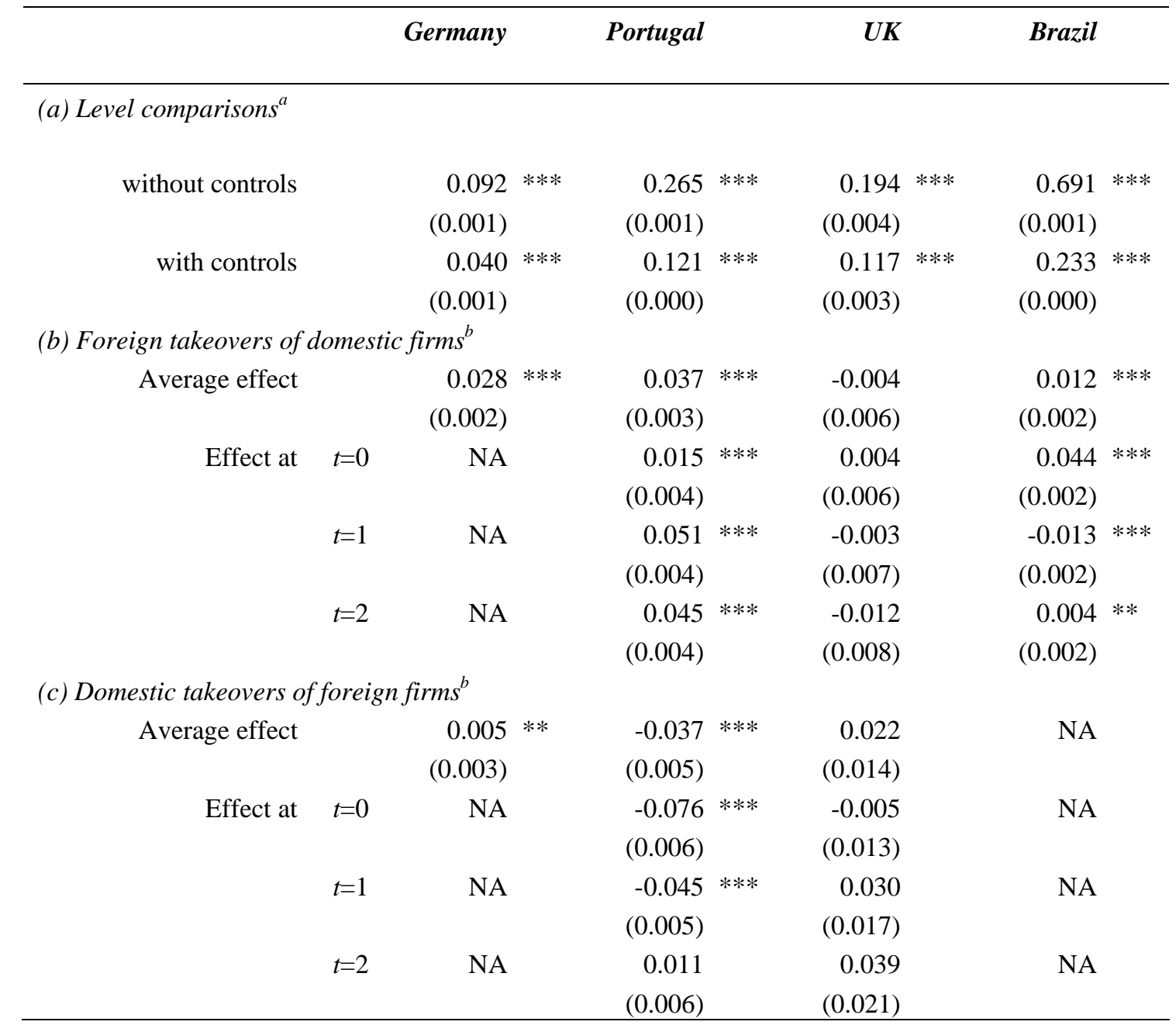

* significant at $10 \%$, ** significant at $5 \%$, *** significant at $1 \%$ confidence interval based on robust standard errors.

${ }^{\text {a }}$ Estimations with OLS.

b Estimations with difference-in-difference propensity-score matching. Coefficients reflect the average percentage differences between the wages of workers whose firm changes ownership status relative to their counterfactual wage had their firm not changed ownership status. 
Table 7: The effects of worker mobility on individual wages

Evidence from linked employer-employee data ${ }^{a}$

\begin{tabular}{|c|c|c|c|c|c|}
\hline & & Germany & Portugal & UK & Brazil \\
\hline \multicolumn{6}{|l|}{ From domestic to foreign firms } \\
\hline \multirow[t]{2}{*}{ Average effect } & & $0.047 * * *$ & $0.136 * * *$ & $0.052 * *$ & $0.213^{* * *}$ \\
\hline & & $(0.016)$ & $(0.005)$ & $(0.017)$ & $(0.009)$ \\
\hline \multirow[t]{6}{*}{ Effect at } & $t=0$ & NA & $0.115^{* * *}$ & $0.040^{*}$ & $0.160 * * *$ \\
\hline & & & $(0.005)$ & $(0.020)$ & $(0.010)$ \\
\hline & $t=1$ & NA & $0.138 * * *$ & $0.059 * *$ & $0.228 * * *$ \\
\hline & & & $(0.005)$ & $(0.021)$ & $(0.010)$ \\
\hline & $t=2$ & NA & $0.154 * * *$ & $0.058 * *$ & $0.252 * * *$ \\
\hline & & & $(0.005)$ & $(0.021)$ & $(0.010)$ \\
\hline \multicolumn{6}{|l|}{ From foreign to domestic firms } \\
\hline \multirow[t]{2}{*}{ Average effect } & & -0.021 & $-0.037 * * *$ & -0.011 & -0.016 \\
\hline & & $(0.017)$ & $(0.005)$ & $(0.026)$ & $(0.009)$ \\
\hline \multirow[t]{6}{*}{ Effect at } & $t=0$ & NA & $-0.050 * * *$ & -0.019 & 0.013 \\
\hline & & & $(0.006)$ & $(0.029)$ & $(0.010)$ \\
\hline & $t=1$ & NA & $-0.040 * * *$ & 0.016 & $0.040 * * *$ \\
\hline & & & $(0.006)$ & $(0.029)$ & $(0.004)$ \\
\hline & $t=2$ & NA & $-0.020 * * *$ & -0.032 & $-0.101^{* * *}$ \\
\hline & & & $(0.006)$ & $(0.030)$ & $(0.011)$ \\
\hline
\end{tabular}

* significant at $10 \%, * *$ significant at 5\%, *** significant at $1 \%$ confidence interval based on robust standard errors.

${ }^{a}$ Estimations are conducted with difference-in-difference propensity-score matching. Coefficients reflect the average percentage differences between the wage of workers who move to a firm with different ownership status relative to their counterfactual outcomes had they not changed jobs. 
Table 8: The effects of cross-border takeovers of domestic firms on wages by skill group Evidence from firm-level data for Brazil and Indonesia ${ }^{a}$

\begin{tabular}{|c|c|c|c|c|c|c|c|}
\hline & & \multicolumn{2}{|c|}{ Brazil } & \multicolumn{4}{|c|}{ Indonesia } \\
\hline & & Unskilled & Skilled & Unskilled & & Skilled & \\
\hline Average effect & & $\begin{array}{r}0.088 \\
(0.075)\end{array}$ & $\begin{array}{r}0.110 * \\
(0.052)\end{array}$ & $\begin{array}{r}0.165 \\
(0.050)\end{array}$ & $* * *$ & $\begin{array}{r}0.276 \\
(0.063)\end{array}$ & $* * *$ \\
\hline Effect at & $t=0$ & $\begin{array}{r}0.011 \\
(0.081)\end{array}$ & $\begin{array}{r}0.112 \\
(0.058)\end{array}$ & $\begin{array}{r}0.167 \\
(0.060)\end{array}$ & $* * *$ & $\begin{array}{r}0.262 \\
(0.060)\end{array}$ & $* * *$ \\
\hline & $t=1$ & $\begin{array}{r}0.113 \\
(0.076)\end{array}$ & $\begin{array}{r}0.093 \\
(0.093)\end{array}$ & $\begin{array}{r}0.142 \\
(0.089)\end{array}$ & & $\begin{array}{r}0.333 \\
(0.118)\end{array}$ & $* * *$ \\
\hline & $t=2$ & $\begin{array}{r}0.142 \\
(0.094) \\
\end{array}$ & $\begin{array}{r}0.125 * \\
(0.058)\end{array}$ & $\begin{array}{r}0.099 \\
(0.105) \\
\end{array}$ & & $\begin{array}{r}0.456 \\
(0.143) \\
\end{array}$ & $* * *$ \\
\hline
\end{tabular}

$*, * *, * * *$ : statistically significant at the $10 \%, 5 \%, 1 \%$ level, respectively, confidence interval based on robust standard errors.

a) Estimations with difference-in-difference propensity-score matching. Coefficients reflect percentage differences between firms that change ownership status relative to their counterfactual value had they remained under domestic ownership. 
Table 9: The effects of cross-border takeovers of domestic firms on wages by skill group

Evidence from linked employer-employee data ${ }^{a}$

\begin{tabular}{|c|c|c|c|c|c|}
\hline & & Germany & Portugal & UK & Brazil \\
\hline \multicolumn{6}{|l|}{ Unskilled workers } \\
\hline \multirow[t]{2}{*}{ Average effect } & & $0.018 * * *$ & $0.019 * * *$ & $-0.025^{* *}$ & $0.054^{* * *}$ \\
\hline & & $(0.004)$ & $(0.005)$ & $(0.008)$ & $(0.004)$ \\
\hline \multirow[t]{6}{*}{ Effect at } & $t=0$ & NA & -0.005 & -0.007 & $0.046^{* * *}$ \\
\hline & & & $(0.006)$ & $(0.009)$ & $(0.005)$ \\
\hline & $t=1$ & NA & $0.031^{* * *}$ & $-0.031 * * *$ & $0.053^{* * *}$ \\
\hline & & & $(0.006)$ & $(0.009)$ & $(0.005)$ \\
\hline & $t=2$ & NA & $0.033^{* * *}$ & $-0.036^{* * *}$ & $0.067^{* * *}$ \\
\hline & & & $(0.006)$ & $(0.010)$ & $(0.005)$ \\
\hline \multicolumn{6}{|l|}{ Semi-skilled workers } \\
\hline \multirow[t]{2}{*}{ Average effect } & & $0.027 * * *$ & $0.053^{* * *}$ & 0.006 & $0.008 * * *$ \\
\hline & & $(0.002)$ & $(0.008)$ & $(0.010)$ & $(0.003)$ \\
\hline \multirow[t]{6}{*}{ Effect at } & $t=0$ & NA & $0.028 * * *$ & 0.009 & $0.048^{* * *}$ \\
\hline & & & $(0.008)$ & $(0.012)$ & $(0.003)$ \\
\hline & $t=1$ & NA & $0.085^{* * *}$ & 0.010 & $-0.019 * * *$ \\
\hline & & & $(0.009)$ & $(0.012)$ & $(0.003)$ \\
\hline & $t=2$ & NA & $0.049 * * *$ & -0.000 & $-0.007^{* *}$ \\
\hline & & & $(0.009)$ & $(0.012)$ & $(0.003)$ \\
\hline \multicolumn{6}{|l|}{ Skilled workers } \\
\hline \multirow[t]{2}{*}{ Average effect } & & $0.014 * * *$ & $0.041^{* * *}$ & 0.001 & $-0.046^{* * *}$ \\
\hline & & $(0.004)$ & $(0.005)$ & $(0.011)$ & $(0.005)$ \\
\hline \multirow[t]{6}{*}{ Effect at } & $t=0$ & NA & $0.022^{* * *}$ & -0.006 & $0.027 * * *$ \\
\hline & & & $(0.006)$ & $(0.013)$ & $(0.006)$ \\
\hline & $t=1$ & NA & $0.050^{* * *}$ & 0.015 & $-0.108 * * *$ \\
\hline & & & $(0.006)$ & $(0.013)$ & $(0.006)$ \\
\hline & $t=2$ & NA & $0.049^{* * *}$ & -0.005 & $-0.061^{* * *}$ \\
\hline & & & $(0.006)$ & $(0.014)$ & $(0.006)$ \\
\hline
\end{tabular}

* significant at $10 \%, * *$ significant at $5 \%, * * *$ significant at $1 \%$ confidence interval based on robust standard errors.

${ }^{a}$ Estimations with difference-in-difference propensity-score matching. Coefficients reflect the average percentage differences between the wage of workers whose firm changes ownership status relative to their counterfactual wage had their firm not changed ownership status. 
Table 10: The effects of foreign takeovers of domestic firms on individual working conditions:

Evidence from linked employer-employee data ${ }^{a}$

\begin{tabular}{|c|c|c|c|c|c|c|}
\hline & & & Germany & Portugal & UK & Brazil \\
\hline \multirow[t]{8}{*}{ (a) Log weekly hours } & \multirow{2}{*}{\multicolumn{2}{|c|}{ Average effect }} & $-0.291^{c}$ & -0.002 & -0.001 & $-0.002 * * *$ \\
\hline & & & $(0.593)$ & $(0.002)$ & $(0.005)$ & $(0.000)$ \\
\hline & \multirow[t]{6}{*}{ Effect at } & $t=0$ & NA & -0.003 & 0.001 & $-0.001 * * *$ \\
\hline & & & & $(0.003)$ & $(0.005)$ & $(0.000)$ \\
\hline & & $t=1$ & NA & $-0.009 * * *$ & * 0.002 & $-0.005^{* * *}$ \\
\hline & & & & $(0.003)$ & $(0.006)$ & $(0.000)$ \\
\hline & & $t=2$ & NA & $0.007 * *$ & -0.006 & 0.000 \\
\hline & & & & $(0.003)$ & $(0.006)$ & $(0.000)$ \\
\hline \multirow[t]{16}{*}{ (b) Worker turnover } & \multirow{2}{*}{\multicolumn{2}{|c|}{ Average effect }} & -0.034 & $0.055^{* *}$ & NA & 0.052 \\
\hline & & & $(0.039)$ & $(0.026)$ & & $(0.043)$ \\
\hline & \multirow[t]{6}{*}{ Effect at } & \multirow[t]{2}{*}{$t=0$} & NA & 0.020 & NA & 0.029 \\
\hline & & & & $(0.020)$ & & $(0.022)$ \\
\hline & & \multirow[t]{2}{*}{$t=1$} & NA & $0.078^{* *}$ & NA & 0.057 \\
\hline & & & & $(0.030)$ & & $(0.048)$ \\
\hline & & \multirow[t]{2}{*}{$t=2$} & NA & $0.066 * *$ & NA & $0.070 *$ \\
\hline & & & & $(0.025)$ & & $(0.040)$ \\
\hline & \multirow[t]{2}{*}{ Average effect } & & \multirow[t]{2}{*}{ NA } & \multicolumn{2}{|c|}{$0.006^{* * *}-0.002$} & $0.001 * * *$ \\
\hline & & & & $(0.002)$ & $(0.004)$ & $(0.001)$ \\
\hline & \multirow[t]{6}{*}{ Effect at } & $t=0$ & NA & -0.000 & -0.006 & 0.001 \\
\hline & & & & $(0.003)$ & $(0.004)$ & $(0.001)$ \\
\hline & & $t=1$ & NA & $0.011^{* * *}$ & * 0.001 & $0.002 * * *$ \\
\hline & & & & $(0.003)$ & $(0.005)$ & $(0.001)$ \\
\hline & & $t=2$ & NA & $0.007 * *$ & 0.000 & 0.001 \\
\hline & & & & $(0.003)$ & $(0.006)$ & $(0.001)$ \\
\hline \multirow[t]{8}{*}{ (d) Union coverage } & \multirow[t]{2}{*}{ Average effect } & & -0.056 & NA & $-0.039 * *$ & NA \\
\hline & & & $(0.078)$ & & $(0.013)$ & \\
\hline & \multirow[t]{6}{*}{ Effect at } & $t=0$ & NA & NA & -0.008 & NA \\
\hline & & & & & $(0.015)$ & \\
\hline & & $t=1$ & NA & NA & $-0.053^{* * *}$ & NA \\
\hline & & & & & $(0.015)$ & \\
\hline & & $t=2$ & NA & NA & $-0.055^{* * *}$ & NA \\
\hline & & & & & $(0.015)$ & \\
\hline
\end{tabular}

* significant at $10 \%$, ** significant at $5 \%$, *** significant at $1 \%$ confidence interval based on robust standard errors.

${ }^{a}$ Estimations with difference-in-difference propensity-score matching.

b The sample is restricted to 1999-2005 due to the introduction of the minimum wage in 1998 in the United Kingdom.

${ }^{\mathrm{c}}$ Estimates are based on standard working hours at the firm-level. 
Table A1. Variable definitions

\begin{tabular}{|c|c|c|c|c|c|}
\hline & Germany & Portugal & United Kingdom & Brazil & Indonesia \\
\hline $\begin{array}{l}\text { Foreign } \\
\text { ownership }\end{array}$ & $\begin{array}{l}\text { More than } 50 \% \text { of } \\
\text { assets owned by a } \\
\text { foreign entity (plant) }\end{array}$ & $\begin{array}{l}\text { More than } 50 \% \text { of } \\
\text { assets owned by a } \\
\text { foreign entity (firm) }\end{array}$ & $\begin{array}{l}\text { More than } 10 \% \text { of } \\
\text { assets owned by a } \\
\text { foreign entity (firm) }\end{array}$ & $\begin{array}{l}\text { More than } 50 \% \text { of } \\
\text { assets owned by a } \\
\text { foreign entity (firm) }\end{array}$ & $\begin{array}{l}\text { More than } 50 \% \text { of } \\
\text { assets owned by a } \\
\text { foreign entity } \\
\text { (plant) }\end{array}$ \\
\hline Employment & $\begin{array}{l}\text { Log total number of } \\
\text { employees }\end{array}$ & $\begin{array}{l}\text { Log total number of } \\
\text { employees }\end{array}$ & $\begin{array}{l}\text { Log total number of } \\
\text { employees }\end{array}$ & $\begin{array}{l}\text { Log total number of } \\
\text { employees }\end{array}$ & $\begin{array}{l}\text { Log total number } \\
\text { of employees }\end{array}$ \\
\hline $\begin{array}{l}\text { Average } \\
\text { wage }\end{array}$ & $\begin{array}{l}\text { Log of the average } \\
\text { individual wage }\end{array}$ & $\begin{array}{l}\text { Log total wage bill } \\
\text { divided by } \\
\text { employment }\end{array}$ & $\begin{array}{l}\text { Log total wage bill } \\
\text { divided by } \\
\text { employment. }\end{array}$ & $\begin{array}{l}\text { Log total wage bill } \\
\text { divided by } \\
\text { employment }\end{array}$ & $\begin{array}{l}\text { Log total wage } \\
\text { bill divided by } \\
\text { employment }\end{array}$ \\
\hline $\begin{array}{l}\text { Individual } \\
\text { wage }\end{array}$ & $\begin{array}{l}\text { Log daily wage, } \\
\text { censored at the social } \\
\text { security ceiling }\end{array}$ & Log hourly wage & $\begin{array}{l}\text { Log gross hourly } \\
\text { wage }\end{array}$ & Log hourly wage & Not available \\
\hline $\begin{array}{l}\text { Working } \\
\text { hours }\end{array}$ & $\begin{array}{l}\text { Log standard working } \\
\text { hours at plant-level } \\
\text { available in 2001, } \\
\text { 2002, } 2004 .\end{array}$ & $\begin{array}{l}\text { Log total working } \\
\text { hours }\end{array}$ & $\begin{array}{l}\text { Log total working } \\
\text { hours }\end{array}$ & $\begin{array}{l}\text { Log total working } \\
\text { hours }\end{array}$ & Not available \\
\hline Low pay & $\begin{array}{l}\text { Germany does not } \\
\text { have a statutory } \\
\text { minimum wage }\end{array}$ & $\begin{array}{l}\text { Dummy equal to } 1 \\
\text { when earning the } \\
\text { minimum wage or } \\
\text { less }\end{array}$ & $\begin{array}{l}\text { Dummy equal to } 1 \\
\text { when earning the } \\
\text { minimum wage or } \\
\text { less }\end{array}$ & $\begin{array}{l}\text { Dummy equal to } 1 \\
\text { when earning the } \\
\text { minimum wage or } \\
\text { less }\end{array}$ & Not available \\
\hline $\begin{array}{l}\text { Collective } \\
\text { agreement }\end{array}$ & $\begin{array}{l}\text { Dummy equal to } 1 \\
\text { when covered by } \\
\text { sectoral or plant-level } \\
\text { agreement }\end{array}$ & $\begin{array}{l}\text { Dummy equal to } 1 \\
\text { when covered by } \\
\text { multi-firm agreement } \\
\text { (defined at plant- } \\
\text { level) }\end{array}$ & $\begin{array}{l}\text { Dummy equal to } 1 \\
\text { when covered by a } \\
\text { collective agreement }\end{array}$ & Not available & Not available \\
\hline Job stability & $\begin{array}{l}\text { The number of worker } \\
\text { separations between t } \\
\text { and t-1 over total } \\
\text { employment at t-1 }\end{array}$ & $\begin{array}{l}\text { The number of } \\
\text { worker separations } \\
\text { between } \mathrm{t} \text { and } \mathrm{t}-1 \\
\text { over total } \\
\text { employment at t-1 }\end{array}$ & Not available & $\begin{array}{l}\text { The number of } \\
\text { worker separations } \\
\text { between } \mathrm{t} \text { and } \mathrm{t}-1 \\
\text { over total } \\
\text { employment at } \mathrm{t}-1\end{array}$ & Not available \\
\hline Industry & 15 categories & Two-digit SIC codes & $\begin{array}{l}\text { One digit SIC92 } \\
\text { codes } \\
\text { (9) }\end{array}$ & $\begin{array}{l}\text { One-digit SIC codes } \\
\text { (9) }\end{array}$ & $\begin{array}{l}\text { SIC codes 15-37 } \\
\text { (23) }\end{array}$ \\
\hline Region & $\begin{array}{l}\text { Bundesländer (11 } \\
\text { regions) }\end{array}$ & Regions (5) & $\begin{array}{l}\text { UK Government } \\
\text { Office Region (10) }\end{array}$ & States (27) & Provinces (34) \\
\hline Sex & $\begin{array}{l}\text { Gender dummy equal } \\
\text { to } 1 \text { when male }\end{array}$ & $\begin{array}{l}\text { Gender dummy equal } \\
\text { to } 1 \text { when male }\end{array}$ & $\begin{array}{l}\text { Gender dummy equal } \\
\text { to } 1 \text { when male }\end{array}$ & $\begin{array}{l}\text { Gender dummy equal } \\
\text { to } 1 \text { when male }\end{array}$ & Not available \\
\hline Age & Age & Age & Age & Age & Not available \\
\hline Skill & $\begin{array}{l}\text { Dummy for high, } \\
\text { semi- and low-skilled } \\
\text { based on highest } \\
\text { educational } \\
\text { qualification }\end{array}$ & $\begin{array}{l}\text { Based on education } \\
\text { groups }\end{array}$ & $\begin{array}{l}\text { Dummy for high, } \\
\text { semi- and low-skilled } \\
\text { based on SOC2000 } \\
\text { 1-digit categories }\end{array}$ & $\begin{array}{l}\text { Based on education } \\
\text { groups }\end{array}$ & $\begin{array}{l}\text { Production and } \\
\text { non-production }\end{array}$ \\
\hline Tenure & $\begin{array}{l}\text { Number of years in } \\
\text { current plant }\end{array}$ & Number of years & $\begin{array}{l}\text { Dummy for }>1 \text { year } \\
\text { in current position in } \\
\text { firm }\end{array}$ & Number of years & Not available \\
\hline
\end{tabular}

